\author{
중등 과학 교과서의 동해 해류도 분석 \\ 박경애 $^{1} \cdot$ 박지은 ${ }^{2, *} \cdot$ 서강선 $^{2} \cdot$ 최병주 $^{3}$ - 변도성 ${ }^{4}$ \\ ${ }^{1}$ 서울대학교 지구과학교육과/해양연구소, $151-742$, 서울특별시 관악구 관악로 1 \\ ${ }^{2}$ 서울대학교 과학교육과, $151-742$, 서울특별시 관악구 관악로 1 \\ 3군산대학교 해양학과, 573-701, 전라북도 군산시 대학로 1170 \\ ${ }^{4}$ 국립해양조사원 해양과학조사연구실, 400-800, 인천광역시 중구 서해대로 365
}

\title{
Analysis of Oceanic Current Maps of the East Sea in the Secondary School Science Textbooks
}

\author{
Kyung-Ae Park', Ji-Eun Park ${ }^{2, *}$, Kang-Sun Seo ${ }^{2}$, \\ Byoung-Ju Choi ${ }^{3}$, and Do-Seong Byun ${ }^{4}$ \\ 'Department of Earth Science Education/Research Institute of Oceanography, \\ Seoul National University, Seoul 151-742, Korea \\ ${ }^{2}$ Department of Science Education, Seoul National University, Seoul 151-742, Korea \\ ${ }^{3}$ Department of Oceanography, Kunsan National University, Jeonbuk 573-701, Korea \\ ${ }^{4}$ Ocean Research Division, Korea Hydrographic and Oceanographic Administration, \\ Incheon 400-800, Korea
}

\begin{abstract}
The importance of scientific education on accurate oceanic currents and circulation has been increasingly addressed because the currents have played a significant role in climate change and global energy balance. The objectives of this study are to analyze errors of the oceanic current maps in the textbooks, to discuss a variety of error sources, to suggest how to produce a unified oceanic current map of the East Sea for the students. Twenty-seven textbooks based on the 7th National Curriculum were analyzed and quantitatively investigated on the characteristics of the current maps by comparing with both the previous literature and up-to-date scientific knowledge. All the maps in the textbooks with different mappings were converted to digitalized image data with Mercator mapping using geolocation information. Detailed analysis were performed to investigate the patterns of the Tsushima Warm Current (TWC) in the Korea Strait, to examine how closely the nearshore branch of the TWC flows along the Japanese coast, to scrutinize the features of the offshore branch of the TWC south of the subpolar front in the East Sea, to quantitatively investigate the northern range of the northward-propagating East Korea Warm Current and its latitude turning to the east, and lastly to examine the outflow of the TWC near the Tsugaru Strait and the Soya Strait. In addition, the origins, southern limits, and distances from the coast of the Liman Current and the North Korea Cold Current were analyzed. Other erroneous expressions of the currents in the textbooks were presented. These analyses revealed the problems in the present current maps of the textbooks, which might lead the students to misconception. This study also addressed a necessity in a bridge between scientists with up-to-date scientific results and educators who needed educational materials.
\end{abstract}

Keywords: oceanic current map, textbook analysis, misconception, the East Sea

요 약: 해류는 기후변화와 지구상의 에너지 균형에 중요한 역할을 하고 있어 정확한 해류와 순환에 대한 과학 교육의 중요성이 점점 더 강조되어 왔다. 본 연구의 목적은 교과서 해류도의 오류를 분석하고, 가능한 원인에 대하여 토의하 며, 학생들에게 동해에 관한 통일된 해류도를 어떻게 제안할 것인지 방안을 제시는 것이다. 제 7 차 교육과정에 근거한 27 종의 교과서를 기존의 문헌과 최근의 과학적 지식과 비교함으로써 동해 해류도의 특성을 정량적으로 분석하고 조사

*Corresponding author: jieun@snu.ac.kr

Tel: + 82-2-880-7780

Fax: +82-2-874-3289 
하였다. 서로 다른 도법을 바탕으로 제작된 교과서 해류도들을 위치 정보를 이용하여 디지털 영상자료로 변환한 후 메 르카토르 도법을 사용하여 새로운 영상으로 전환하였다. 대한해협에서의 대마난류 분지 양상과 대마난류의 근해 분지가 일본 연안에 얼마나 근접하여 북상하는지를 정량적으로 조사하고, 동해 극전선 이남에서 사행하는 대마난류의 외해 분 지의 양상을 면밀히 분석하였으며, 우리나라 동해안을 따라 북상하는 동한난류의 북상 범위, 이안 위도도 조사하였고, 난류의 유출 양상을 쓰가루 해협과 소야 해협 부근에서 분석하였다. 또한 리만해류와 북한한류가 시작하는 위도, 남하 하는 범위, 연안에 근접한 정도에 대하여 분석하였다. 이외에도 교과서 해류도에 대한 잘못된 표현도 제시하였다. 이러 한 분석들은 교과서 해류도의 문제점을 드러내었으며, 이는 학생들에게 오개념을 일으킬 수 있다. 본 연구는 최신의 과 학적 연구 결과를 가지고 있는 과학자들과 교육 자료가 필요한 교육자들 사이에 연결 고리의 필요성도 강조하였다.

주요어: 해류도, 교과서 분석, 오개념, 동해

\section{서 론}

최근 지구온난화와 기후 변화 문제가 심각하게 대 두됨에 따라 지구상의 열의 수송자로서 해양순환의 역할이 점점 더 강조되고 있다(Ganachaud and Wunsch, 2000). 해양의 순환은 크게 표층의 풍성순환과 심층 의 열염분순환으로 나눌 수 있는데, 이 두 순환은 독 립적으로 각각 떨어져있는 것이 아니라 '컨베이어벨 트(conveyor belt)'라고 불리는 전 지구 규모의 거대 한 순환으로 서로 유기적으로 연결되어 에너지의 불 균형을 해소하고 기후 변화를 주도하고 있다. 최근의 연구 결과는 지구온난화의 영향으로 컨베이어벨트의 시작점이라고 할 수 있는 대서양 북부에서 심층수 형성이 약화되고 있음을 보여주고 있다. 특히 1957년 부터 2004년까지 지난 수십 년 간의 해양관측 자료 를 분석한 결과, 대서양의 자오면 해수 순환 (meridional overturning)의 속도가 $30 \%$ 나 감소되었음 이 밝혀졌다(Bryden et al., 2005). 이러한 순환의 변 화는 해양-대기 상호작용을 통하여 기후변화를 유도 하고 있으며, 먼 바다의 변화가 우리의 일상생활에까 지 일기변화로 영향을 미치고 있다.

해류는 해양에서 특정한 방향으로 지속적으로 흐르 는 해수의 흐름을 말하며(한국해양학회, 2005), 해양 의 순환을 구성하는 가장 기본적인 요소 중의 하나 이다. 해류로 인해 해양은 대기보다 수 배 이상의 열 을 극지방으로 이동시키고 에너지 분포를 조절함으로 써 해수 온도를 포함한 지구의 온도가 급변하지 않 도록 조절하고 있다(IPCC, 1996; Macdonald and Wunsch, 1996). 또한 용존 산소나 영양염, 오염물질 을 운반해 해양생태계와 어장형성 등에 지대한 영향 을 주어 지역 경제와도 밀접한 관련이 있다(Lynn et al., 1998; McGowan et al., 1998; Lavaniegos and Ohman, 2003; Lavaniegos and Ohman, 2007). 전 지
구규모로 천문학적인 피해를 주고 있는 엘리뇨와 라 니냐는 먼 적도태평양에서 해양의 표층 해류의 방향 변화와 관련이 있다(Johnson et al., 2000). 따라서 해 류는 앞으로의 기후 변화를 예측하는데 있어 매우 중요한 변수이며 전 지구적 규모뿐만 아니라 우리나 라 주변해와 같은 국지적인 해역에서도 지속적으로 감시되어야 한다.

기후변화에 대한 해류의 역할이 중요해지면서 정확 한 해류 교육에 대한 필요성이 커지고 있다. 제 7차 중등 교육과정은 해류에 관한 내용을 중학교 1학년 과학, 고등학교 1 학년 과학, 고등학교 2 학년 지구과 학 I에서 다루고 있다. 해류를 이해하는 가장 기본적 인 요소는 해류도이다. 그런데 7차 교육과정의 각 과 학 교과서는 서로 상이한 해류도를 제시하고 있으며 이들 중 상당수는 과학적 사실과 다른 형태를 보이 고 있다.

중등학교에서 학생들은 교육과정과 관련된 대부분 의 지식을 교과서를 통해 습득하고 있으며 과학 교 과서는 교육 목표를 달성하기 위한 교육과정의 기본 정신에 따라 교과 내용을 효율적으로 구성한 교재로 서 과학 수업에서 중요한 요소이다(Ball and FeimanNemser, 1988; Tobin, 1990; Abraham et al., 1992). 따라서 교과서는 학생들이 개념을 습득하고 이해하기 위한 주요 수단이 되며, 실제로 학교 교육에 있어서 교과서에 대한 교사와 학생의 의존도는 매우 크다 (Chian-Soong and Yager, 1993). 과학 교과서에 관한 한 설문조사에서는 조사대상 교사의 $89.9 \%$, 학생의 $85.4 \%$ 가 교수 학습에 있어 교과서에 의존하고 있음 을 밝혔다(최경희와 김숙진, 1996).

과학 교과서에 등장하는 삽화는 현행 과학 교과서 에서 핵심적인 시각적 표상 요소 중의 하나로서(이기 영, 2007), 본문과 같이 선형적이지 않고 색과 영역 을 가진 2차원 배열을 가지며 글로는 제공하지 못하 
는 추가적인 정보를 제공해 줄 수 있다(Pozzer and Roth, 2003). 과학 교과서는 학생들이 직접 눈으로 확인하기 힘든 자연 현상을 다양한 삽화나 그림, 사 진 자료, 도표 등을 통하여 간접적으로 경험하도록 한다(채동현, 2010). 그러나 교과서의 개념 진술이나 그림, 도표 등은 오개념을 유발하고 강화할 가능성도 높다(최승일과 조희형, 1987; 국동식, 2003; 오원근, 2003; Driver at al., 1985).

우리나라 주변해는 크게 동해, 황해, 동중국해 세 가지로 나뉜다. 중등학교 과학 및 지구과학 교과서 해류도에서 제시하고 있는 해류가 포함된 영역은 매 우 다양하지만 대부분의 경우 세 바다를 포함하고 있다. 그런데 동해와 황해는 여러 가지 측면에서 볼 때 그 특성이 매우 다른 바다이다. 동해에서 깊은 곳의 수심은 $3000 \mathrm{~m}$ 이상에 달하나 황해는 평균 수 심이 약 $45 \mathrm{~m}$ 정도인 매우 얕은 바다이다(Fig. 1). 두 해역에서 일어나는 해양 현상은 역학적으로도 서 로 다른 요인과 과정에 의해 일어나고 있다. 동해는 대양에서 일어나는 거의 대부분의 현상들이 일어나 며 해류의 순환 모습이 대양과 매우 유사하여 '작은 대양(miniature ocean)'으로 불린다(Ichiye, 1984; Kim et al., 2001). 또한 동해는 대한해협, 쓰가루해 협, 소야해협 및 타타르 해협을 통하여 북서태평양과 오호츠크해와 연결되는데 이들 해협의 수심은 매우 낮고 그 폭이 좁아서 주변 해로의 해수 흐름은 제한 적이다(Sugimoto, 1990$) .40^{\circ} \mathrm{N}$ 부근의 극전선을 경 계로 남쪽의 대마난류 수역과 북쪽의 한류수역으로 구분되며(Park et al., 2004) 조석에 의한 영향은 매 우 작은 편이다(Kang et al., 1991). 반면에 황해는 계절 몬순과 얕은 깊이로 인하여 계절변동이 매우 크다. 여름에는 더욱 복잡한 양상을 보이는데 양쯔강 저염수가 잘 발달하여 제주 해협을 통한 유출이 발 생한다(Beardsley et al., 1985; Park, 1986). 황해 전 체 해류는 대체로 시계방향으로 순환하나 일반적인 역학은 잘 알려지지 않고, 북쪽으로 향하는 기후학적 평균 흐름으로 알려진 황해난류가 있지만(Nitani, 1972) 강한 조류와 바람의 영향을 받아 해류를 예측 하거나 모델화하기 쉽지 않다(Teague and Jacobs, 2000). 이와 같이 동해와 황해는 해류를 함께 논하기 에는 그 성격이 매우 다르고 복잡하기 때문에 본 연 구에서는 교과서의 동해 해류에 대해서 집중적으로 분석하고자 한다.

2011년 현재 교육과정이 일부 변경이 되어 새로운

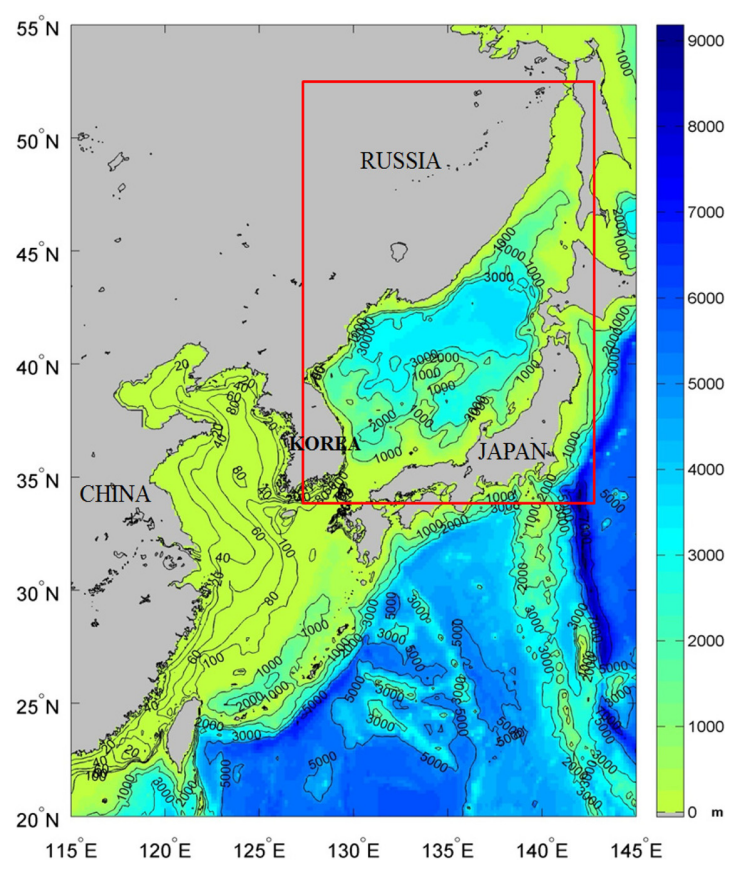

Fig. 1. Bathymetry in the seas around Korea, where the colors represent water depths and the red box represents the study area of the East Sea.

교과서가 활용되고 있으나 해류도 부분은 아직 다루 고 있지 않기 때문에 본 연구에서는 7차 교육과정에 따른 교과서를 분석하였다. 중등 과학 및 지구과학 교과서에 제시되어 있는 동해에 대한 다양한 해류도 의 특성과 차이점을 제시하기 위하여 1) 교과서에서 제시하고 있는 각 해류도를 전산화하여 동일한 도법 를 활용한 디지털자료로 변환하고, 2) 각 해류도간의 차이를 통계적으로 분석하여, 3) 지금까지 밝혀진 과 학적 사실과 비교하여 현행 교과서에서 제시하는 해 류도의 오류를 각 항목별로 조사하고, 4) 또한 분석 결과와 과학적 사실에 근거하여 과학 및 지구과학 교과서의 해류도를 통일화할 수 있는 방안을 제시하 고자 한다.

\section{연구 내용 및 방법}

\section{분석교과서 종류}

2011년 현재 2007, 2009 개정 교과 교육과정이 단 계별로 적용 중에 있고, 2011 개정 교과 교육과정은 개발 중에 있어서 2001년부터 중· 고등학교에 적용 중인 제 7차 교육과정을 중심으로 해류를 다루고 있 
Table 1. Information of the textbooks analyzed for the study

\begin{tabular}{|c|c|c|c|c|}
\hline Course & Textbook & Authors (year) & Pages & Symbol \\
\hline \multirow{9}{*}{$\begin{array}{c}\text { 7th } \\
\text { grade } \\
\text { Science }\end{array}$} & \multirow{9}{*}{$\begin{array}{l}\text { Middle } \\
\text { school } \\
\text { Science }\end{array}$} & Kang et al. (2000) & 239 & M1 \\
\hline & & Kim J.Y. et al. (2000) & 233 & M2 \\
\hline & & Kim C.J. et al. (2000) & 247 & M3 \\
\hline & & Park et al. (2000) & 245 & M4 \\
\hline & & So et al. (2000) & 227 & M5 \\
\hline & & Lee G.M. et al. (2000) & 234 & M6 \\
\hline & & Lee S.M. et al. (2000) & 249 & M7 \\
\hline & & Chung et al. (2000) & 242 & M8 \\
\hline & & Choi et al. (2000) & 241 & M9 \\
\hline \multirow{12}{*}{$\begin{array}{c}\text { 10th } \\
\text { grade } \\
\text { Science }\end{array}$} & \multirow{12}{*}{$\begin{array}{c}\text { High } \\
\text { school } \\
\text { Science }\end{array}$} & Kang et al. (2001) & 285 & Hal \\
\hline & & Kim C.J. et al. (2001) & 272 & $\mathrm{Ha} 2$ \\
\hline & & Sung et al. (2001) & 301 & Ha3 \\
\hline & & Song et al. (2001) & 292 & Ha4 \\
\hline & & Wu et al. (2001) & 297 & Ha5 \\
\hline & & Lee G.S. et al. (2001) & - & Ha6 \\
\hline & & Lee M.W. et al. (2003) & 272 & Ha7 \\
\hline & & Lee M.W. et al. (2002) & 315 & $\mathrm{Ha} 8$ \\
\hline & & Lee Y.W. et al. (2001) & 258 & $\mathrm{Ha} 9$ \\
\hline & & Jung et al. (2001) & 275 & Ha10 \\
\hline & & Cha et al. (2001) & 261 & Ha11 \\
\hline & & Hyun et al. (2007) & 209 & Ha12 \\
\hline \multirow{6}{*}{$\begin{array}{c}11 \text { th } \\
\text { grade } \\
\text { Science }\end{array}$} & \multirow{6}{*}{$\begin{array}{c}\text { Earth } \\
\text { Science } \\
\text { I }\end{array}$} & Kyung et al. (2002) & 162 & $\mathrm{Hb} 1$ \\
\hline & & Kim et al. (2002) & 143 & $\mathrm{Hb} 2$ \\
\hline & & Wu et al. (2002) & 131 & $\mathrm{Hb} 3$ \\
\hline & & Lee G.S. et al. (2002) & 149 & $\mathrm{Hb} 4$ \\
\hline & & Lee M.W. et al. (2002) & 178 & $\mathrm{Hb} 5$ \\
\hline & & Ho et al. (2002) & 154 & $\mathrm{Hb} 6$ \\
\hline
\end{tabular}

는 중학교 1 학년 과학, 고등학교 과학, 지구과학 I 교 과서 27종을 Table 1과 같이 선정하여 연구에 활용 하였다. 사용한 교과서들은 종류마다 구분하여 편의 상 기호를 붙였다(박경애와 최지영, 2009). 예를 들면 공통기본교육과정 7학년 과학 교과서는 중학교 학생 들이 배우고 있기 때문에 'Middle school'의 ' $\mathrm{M}$ '을 따서 교과서 종류마다 구분하여 각각 M1, M2, M3 등으로 기호를 붙였다. 10 학년 과학과 선택 및 심화 과정 지구과학 I은 고등학교 학생들이 배우고 있기 때문에 'High school'의 ' $\mathrm{H}$ '를 따서 10학년 과학 과 정은 ' $\mathrm{Ha}$ ', 지구과학 $\mathrm{I}$ 은 ' $\mathrm{Hb}$ '로 기호를 붙였다. Table 1에 각 교과서에 관한 저자, 해류 관련 페이지, 그리고 교과서 표기 기호를 나타내었으며, 출판사 및 전체 페이지 수에 관한 정보는 참고문헌에 제시하였 다. Fig. 2는 27종의 교과서에서 제시하고 있는 평균 해류도의 영상만을 모은 것으로, 이 영상들을 해류도 분석에 활용하였다.

\section{도법 통일화 과정}

Fig. 2와 같이 각 교과서에 실린 해류도는 위 - 경 도 범위가 모두 다르며 제각각 다양한 도법을 활용 하고 있다. 다른 도법을 사용한 해류도들은 서로 정 성적으로 비교될 수 있지만 해류의 여러 가지 특성 을 정량적으로 비교하는 것은 불가능하다. 도법이 다를 경우 해류도를 해석하는데 있어 시각적으로 왜곡이 생길 수 있기 때문에 제시된 해류도를 모두 동일한 도법으로 통일하여 비교하는 것이 바람직하 다. 다양한 종류의 도법 중에서 가장 보편적으로 사 용되어온 도법은 메르카토르(Mercator) 도법이다. 이 도법은 원통도법(cylindrical projection) 방식으로 적도에서 멀어질수록 지형의 왜곡이 심하게 나타날 수 있지만 지도상에서 위도선과 경도선이 나란하게 나타나서 편리한 점이 많다. 따라서 본 연구에서도 동일한 도법을 적용하기 위하여 각 아날로그 영상 해류도들을 전산 처리하여 디지털 영상정보신호로 변환하고 메르카토르도법으로 통일화하는 작업을 하 였다.

대부분의 교과서 해류도는 메르카토르도법을 사용 하였지만, M8, $\mathrm{Ha} 1, \mathrm{Ha} 5, \mathrm{Ha} 10, \mathrm{Hb} 5, \mathrm{Hb} 6$ 교과서들 은 지구본의 중심에서 지구본에 씨운 원추에 경도선 과 위도선을 투영하고 이를 다시 펼쳐 평면으로 만 드는 원추도법(conical projection)을 사용하여 해류도 를 표현하였다. 이러한 메르카토르 이외의 도법뿐만 아니라 메르카토르도법을 활용한 것으로 유추되는 해 류도들도 모두 스캔하여 전산처리하는 과정을 거쳤 다. 교과서 해류도의 영역 또한 동일하지 않기 때문 에 한반도 주변해의 해류가 모두 포함될 수 있도록 $118-155^{\circ} \mathrm{E}, 25-55^{\circ} \mathrm{N}$ 해역을 도법 통일을 위한 영역으 로 정하였으며, 디지털 전산 작업이 완성된 후에는 이 중에서 $128-144^{\circ} \mathrm{E}, 33.5-48.5^{\circ} \mathrm{N}$ 영역을 동해로 선 정하여 연구에 활용하였다. 한반도를 포함한 광역의 영역을 우선 선정한 것은 지형보정과정에서 발생할 수 있는 오차를 최소한으로 감소시키기 위하여 의도 적으로 넓게 정하였다.

Fig. 3은 좌표변환 과정을 통해 각 해류도를 메르 카토르 도법으로 통일한 후 디지털화하는 과정을 나 타낸 것이다. 먼저 각 해류도를 스캔하여 $\mathrm{JPEG}$ 파일 로 저장한 후 메르카토르 도법인지 아닌지를 구분하 였다. 메르카토르 도법이 아닐 경우 특이한 해안선 모양과 실제 해안선 좌표를 비교하여 $\mathrm{GCP}(\mathrm{Ground}$ Control Point)들을 선정하고, 좌표 변환식을 이용하 


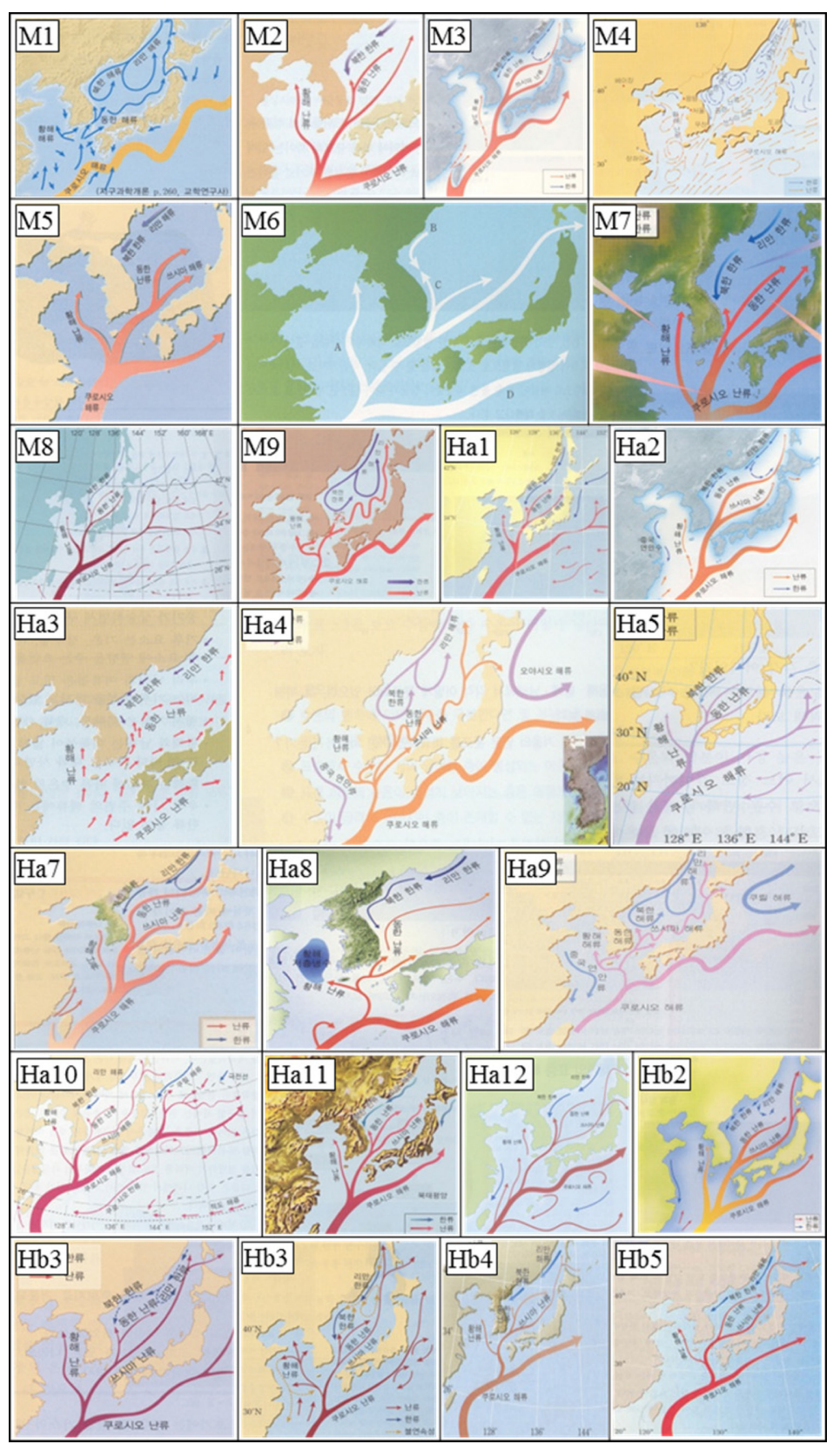

Fig. 2. Oceanic current maps in the secondary school science and earth science textbooks, where the symbols represent the notation of each textbook.

여 지형보정(geometric correction)하는 과정을 거치도 록 하였다. 스캔된 해류도 영상은 각 화소가 공간좌 표 정보를 포함하고 있지 않기 때문에 $\mathrm{GCP}$ 좌표들 은 컴퓨터 화면 상에서 공간좌표 정보가 알려진 기 존 자료와 수동으로 비교하여 선정하였다. 해류도 이 미지 상에서 위·경도 좌표를 알고 있는 $\mathrm{GCP}$ 들을 지 정한 후 디지털 영상의 각 화소들을 다항식 보간법 (polynomial interpolation) 변환 방식으로 알려진 공 간좌표와 맞추었다. 변환된 해류도의 공간 해상도는 $0.02^{\circ} \times 0.02^{\circ}$ 로 하였으며, 해류도 영상의 화소들이 가 지고 있는 RGB (Red Green Blue) 색상 정보와 위 • 경도 위치 정보를 아스키 파일로 출력하였다.

한류와 난류를 별도로 분석하기 위하여 교과서 해 류도를 보면서 난류와 한류를 구분하여 고유한 디지 


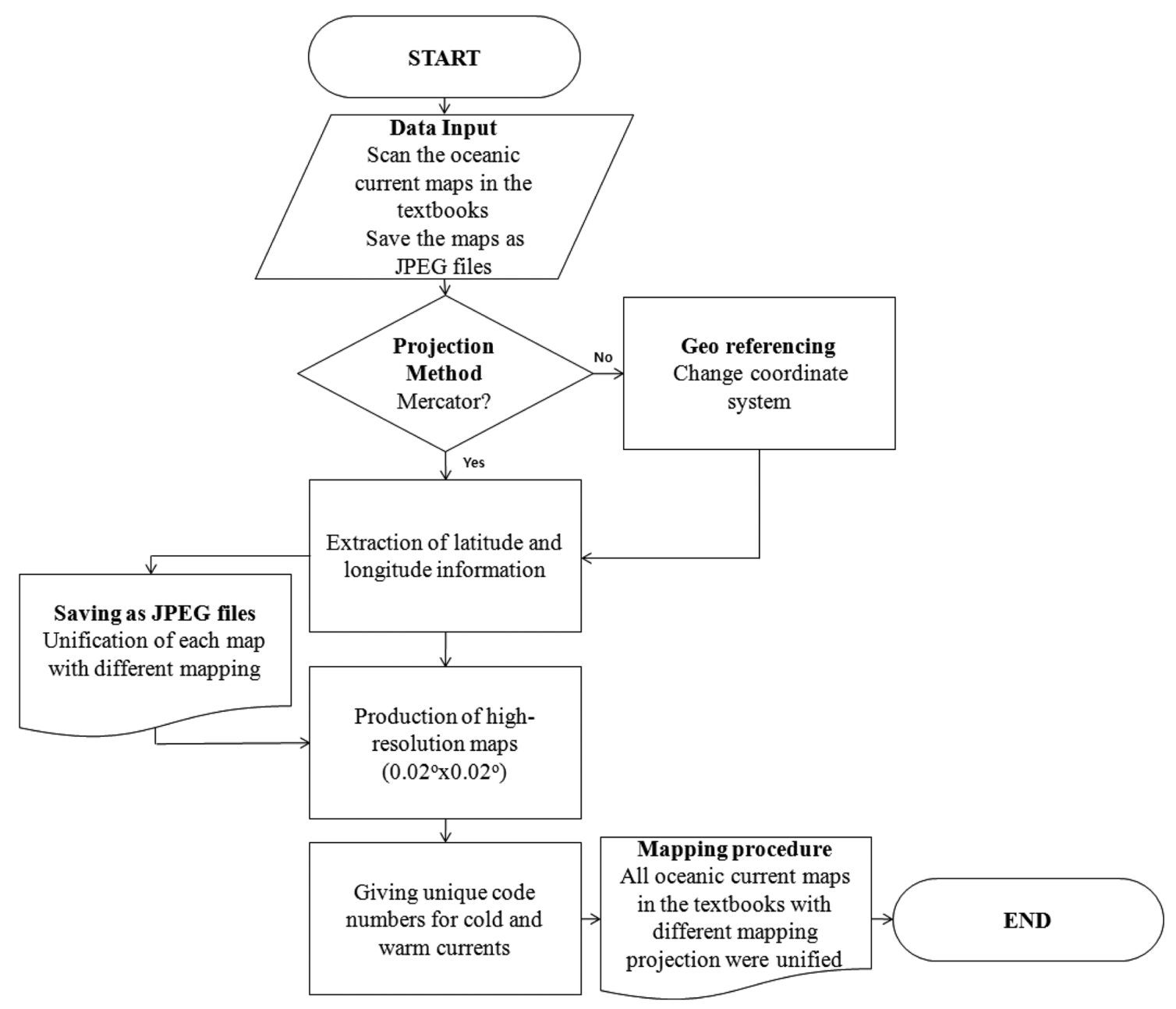

Fig. 3. A flow diagram for the unification of ocean current maps in the textbooks.

털 숫자를 수동으로 부여하였다. 이 때 한류와 난류 를 동일한 색상으로 표현한 해류도는 기존의 과학적 지식을 바탕으로 판단하여 수동으로 고유 숫자를 주 었다. 이러한 과정을 통하여 서로 다른 해류도를 동 일한 도법으로 통일할 수 있었고, 위치 정보와 색상 정보를 모두 획득할 수 있게 되었다. 이러한 기초적 인 정보들은 다음 단계에서 해류도를 정량적으로 분 석하는데 활용하였다.

\section{분석 항목}

동해의 해류는 크게 한류와 난류 계통으로 나누어 볼 수 있지만, 동해의 수심, 해저 지형, 해안선이 복 잡하고 동해 남부는 복잡한 계절 변동을 가지고 있어 서 두 해류계를 해류도에 간단히 나타내는 것은 쉬운 일이 아니다. 해류의 크기와 진행방향의 특징을 가장
잘 표현하기 위해서는 해류도를 분석할 항목을 가능 한 상세히 작성할 필요가 있다. 따라서 실제 동해 해 류에 대한 그 동안의 과학적 논문과 논의를 바탕으로 Table 2에서 보는 바와 같이 각 소주제에 대하여 구 체적인 세부항목을 작성하였고, 각 항목은 편의상 $\mathrm{Cl}$ 과 같이 기호를 각각 붙였다. 이 분석 항목들에 기초 하여 각 교과서의 해류도를 비교 분석하였다.

우선 대한해협을 통과할 때 대마난류의 모습, 동해 안을 따라 북상하는 동한난류, 일본 연안과 동해 남 부 해역의 대마난류의 모습, 태평양과 연결되어 있는 해협 근처에서의 해류의 모습, 그리고 한류로 크게 분류하였고, 나머지 세세한 부분은 $\mathrm{C} 11$ 에서 $\mathrm{C} 16$ 까지 기타 사항을 두어 분석할 수 있도록 하였다.

$\mathrm{C} 1$ 은 대한해협에서의 해류 분지가 어떤 형태로 나 타나는지에 대한 분석 항목이고, $\mathrm{C} 2$ 와 $\mathrm{C} 3$ 은 동한난 
Table 2. Topics and detailed contents for the deep analyses of oceanic current maps in the secondary school science textbooks

\begin{tabular}{cll}
\hline \hline Subjects & Item \# & \multicolumn{1}{c}{ Analysis contents } \\
\hline The Korea Strait & C1 & Bifurcation of the Tsushima Warm Current in the Korea Strait \\
\hline The East Korea & C2 & Distances of the main axis of the East Korea Warm Water from the east coast of Korea \\
Warm Current & C3 & Northern limit of the East Korean Warm Water \\
\hline The Tsushima & C4 & How closely the Tsushima Warm Current flows from the Japanese coast? \\
Warm Current & C5 & How does it describe the paths of the Tsushima Warm Current in the southern region of the \\
& Cast Sea? & Flow patterns of the Tsushima Warm Current west of the Tsugaru Strait \\
Outflow through channels/ & C7 & Flow patterns of the Tsushima Warm Current west of the Soya Strait \\
Return current & C8 & Return current of the Tsushima Warm Current from north of the Tsugaru Strait toward the \\
& Russian coast \\
\hline \multirow{2}{*}{ Cold current } & C10 & Feature of the Liman Current \\
& Feature of the North Korea Cold Current \\
& C12 & Proper usage of colors corresponding to the warm and cold current \\
& C13 & References or sources of the current maps \\
C14 & Name of each current \\
C15 & Seasonal oceanic current maps \\
C16 & Deep or intermediate current
\end{tabular}

류가 북상할 때 난류의 주축이 연안으로부터 얼마나 떨어져 있고, 또 동한난류의 북상 범위를 어느 위도 까지로 볼 것인지에 관한 것이다. $\mathrm{C} 4$ 와 $\mathrm{C} 5$ 는 대마난 류에 관한 내용으로서 대마난류가 일본 연안을 따라 북상할 때 연안에 어느 정도 근접해서 진행하고 있 는지, 또 극전선 이남의 동해 남부에서 대마난류의 분지와 관련하여 어떤 모습으로 표현하고 있는지에 관한 항목으로 구성하였다. C6-C8은 동해가 태평양 으로 연결되는 해협 근처에서의 해류의 형상에 관한 항목으로서 대마난류가 쓰가루해협과 소야해협에서 북태평양으로 일부 빠져나가고 일부는 북상하고 있는 모습을 잘 표현하고 있는지, 또한 쓰가루해협을 지나 북상한 대마난류가 러시아를 향하는 해류의 모습 즉 북상하는 난류의 유출과 환류(return current)에 관하 여 중점적으로 분석하도록 하였다. $\mathrm{C} 9$ 와 $\mathrm{C} 10$ 항목에 서 북한한류와 리만해류 등 동해의 한류에 관한 내 용과 표현을 조사하였고, $\mathrm{C} 11$ 부터 $\mathrm{C} 16$ 까지는 기타 항목으로 두어서 주요 해류의 방향 표시 외에 영상 자료로서 가시적인 표현의 역할을 할 때 부수적인 것들을 분석하도록 설계하였다. 예를 들면 해류도에 서 한류와 난류의 색상 선택 여부, 해류의 크기 정도 는 어떻게 나타내었는지, 또한 참고한 해류도의 출처 및 참고문헌을 제대로 인용하였는지, 해류 이름의 통 일성 여부, 계절별 해류도의 제시 여부, 심층해류에 관한 항목 등으로 구성하였다.

\section{연구 결과 및 논의}

\section{도법 통일화}

해류를 다루고 있는 7차 교육과정 과학/지구과학 I 27종 교과서 중에서 $\mathrm{Ha} 6, \mathrm{Hb} 1$ 을 제외한 25 종의 교 과서가 평균 해류도를 제시하고 있었다. 계절별 해류 도는 $\mathrm{Hb} 1, \mathrm{Hb} 5, \mathrm{Hb} 6$ 의 3종 교과서가 제시하였고, 평균 해류도와 계절별 해류도를 모두 제시한 교과서 는 $\mathrm{Hb} 5$ 와 $\mathrm{Hb} 6$ 였다. 이 중 25 종 교과서의 평균 해류 도를 디지털 자료로 만들었다. 원추 도법으로 그려진 $\mathrm{M} 8, \mathrm{Ha} 1, \mathrm{Ha} 5, \mathrm{Ha} 10, \mathrm{Hb} 5, \mathrm{Hb} 6$ 은 메르카토르 도법 으로 변환하면서 다른 교과서 해류도에 비해 상대적 으로 큰 변화가 발견되었다.

Fig. 4는 M8 교과서가 제시한 해류도와 도법 변환 을 실시하고 전산처리한 해류도를 나타낸 것이다. Fig. $4 \mathrm{a}$ 에서는 위도선이 동심원의 호를 이루고 있지 만, 메르카토르 도법으로 변환된 해류도인 Fig. $4 \mathrm{~b}$ 에 서는 해류의 원래 위·경도 좌표는 변화 없이 위·경 도선이 서로 평행하다. 도법 변환 전의 경우 다른 해 류도와 비교하려고 해도 각 해류의 위치와 진행 방 향 등을 정량적으로 해석할 수 없어서 비교가 매우 제한적이었다. 그러나 모든 해류도를 이와 같이 하나 의 도법으로 좌표 변환을 실시함으로써 교과서 각 해류도들 사이의 정량적인 특징을 분석할 수 있게 되었다. 

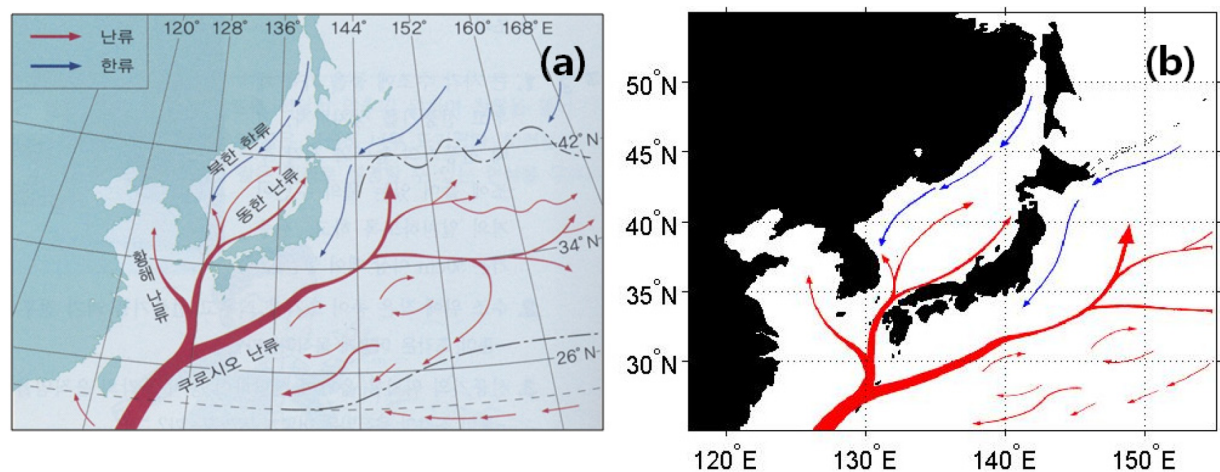

Fig. 4. Oceanic current maps in the seas around Korea (a) before and (b) after the unification procedure of image mapping for the textbook M8.

평균 해류도를 제시한 25 종의 교과서들을 중학교 과학, 고등학교 1 학년 과학, 지구과학 I의 과정별로 나누고 난류와 한류를 구분하여 디지털 수치화한 해 류도를 Fig. 5에 제시하였다. Fig. 5a, 5c, 5e는 난류 를 나타낸 것이고 Fig. $5 \mathrm{~b}, 5 \mathrm{~d}, 5 \mathrm{f}$ 는 한류를 모아 표 현한 것이다. 여기서 각 색상은 오른쪽에 있는 색상 지수표와 같이 교과서의 종류를 나타낸다. 각 교과서 의 해류들을 겹쳐서 조사한 결과, 해류의 크기와 위 치, 그리고 진행 방향에 있어서 제각각인 것을 시각 적으로 구별할 수 있었다. 예를 들면, Fig. 5a의 M9 교과서는 대마난류가 일본 연안을 따라서 사행하면서 북상하는 것으로 도시하였지만, $\mathrm{Ha} 12$ 교과서는 거의 굴곡 없이 연안을 따라 북상하는 것으로 표현하고 있어 두 해류도 사이의 차이점을 쉽게 발견할 수 있 다. 또한 한류를 표현한 것도 차이가 나는데, Fig. $5 \mathrm{~d}$ 에서 $\mathrm{Ha} 9$ 교과서는 동해 극전선 이북에서 동쪽과 서 쪽에 두 개의 큰 환류를 그린데 반해, 그 외 대부분 의 $\mathrm{Ha}$ 교과서들은 러시아 연안에 근접하면서 연안선 과 평행하고 거의 직선에 가까운 완만한 곡률을 가 진 선으로 표현하고 있었다. 난류 중에서는 Fig. 5a 의 M1과 M4 교과서는 제시된 여러 가지 해류도들 중에서 가장 높은 위도까지 대마난류가 북상하도록 표시하였고, 한류 중에서는 Fig. 5d의 Hal이 가장 높 은 위도에서부터 남하하는 것으로 나타내고 있어서 차이점이 확연히 부각되었다. 따라서 디지털 수치화 된 해류도를 바탕으로 지금까지 보고되어 온 과학적 사실에 기반하여 각 해류도들이 가지는 문제점들을 파악하였다.

\section{대한해협 부근 해류}

동해로 유입하는 고온 고염의 대마난류를 정확하게
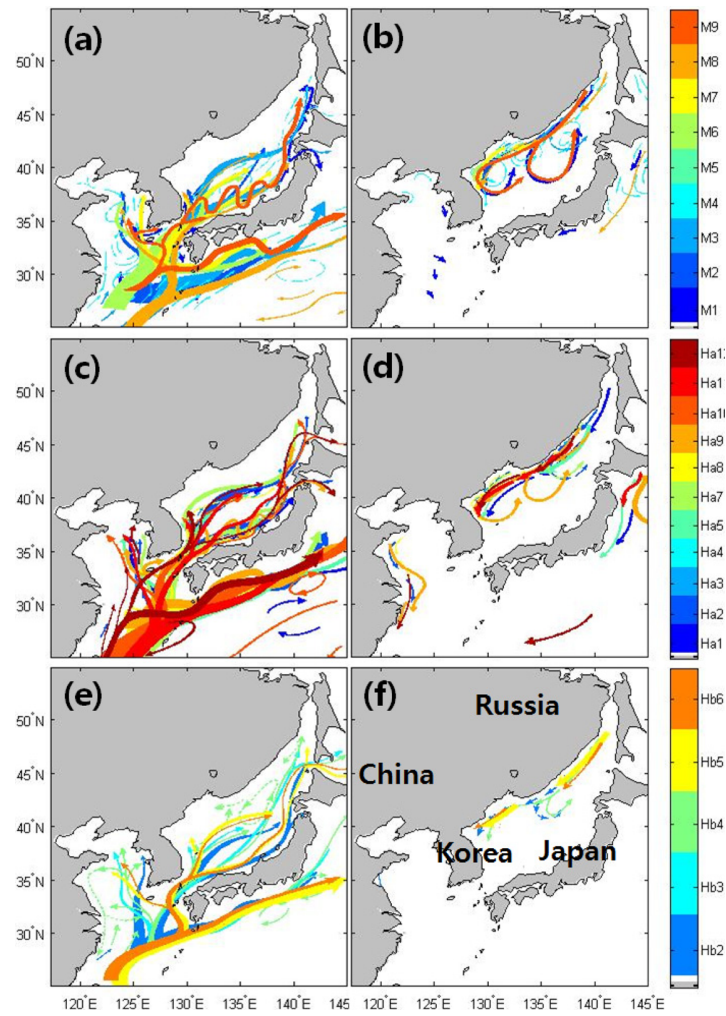

Fig. 5. Oceanic current maps in the seas around Korea for (a) warm current and (b) cold current in the middle school science textbooks, (c) warm current and (d) cold current in the high school science textbooks, and (e) warm current and (f) cold current in the earth science I textbooks.

표현하기 위해서는 동해 입구인 대한해협 부근에서 대마난류를 어느 정도 제대로 가시화하고 있는지를 먼저 확인하여야 한다. 이를 위해 각 교과서에서 제 시한 해류도 중 대한해협에서 난류가 동해로 유입되 
Table 3. A chart showing the analysis results of textbooks concerning the analysis items from $\mathrm{C} 1$ to $\mathrm{C} 16$, where $\mathrm{O}, \triangle$, and $\mathrm{X}$ represent 'satisfied', 'partially satisfied/unsatisfied', and 'unsatisfied', respectively

\begin{tabular}{|c|c|c|c|c|c|c|c|c|c|c|c|c|c|c|c|c|}
\hline Textbooks & Items $\mathrm{Cl}$ & $\mathrm{C} 2$ & C3 & C4 & C5 & C6 & C7 & C8 & C9 & $\mathrm{C} 10$ & C11 & $\mathrm{C} 12$ & $\mathrm{C} 13$ & C14 & $\mathrm{C} 15$ & C16 \\
\hline M1 & $\mathrm{O}$ & $\mathrm{O}$ & $X$ & $\triangle$ & $\triangle$ & $\mathrm{O}$ & $\mathrm{O}$ & $\mathrm{O}$ & $\mathrm{O}$ & $\mathrm{O}$ & $X$ & $\triangle$ & $\mathrm{O}$ & $\triangle$ & $X$ & $X$ \\
\hline M2 & $X$ & $\triangle$ & $\mathrm{O}$ & $X$ & X & $X$ & X & X & $\mathrm{O}$ & $\mathrm{O}$ & O & $\triangle$ & $\mathrm{O}$ & $\triangle$ & $X$ & $X$ \\
\hline M3 & $X$ & $\triangle$ & X & $\triangle$ & $X$ & $\triangle$ & $\triangle$ & $X$ & $\mathrm{O}$ & $\mathrm{O}$ & $\mathrm{O}$ & $\mathrm{O}$ & $\mathrm{O}$ & $\mathrm{O}$ & $X$ & $X$ \\
\hline M4 & $\mathrm{O}$ & $\triangle$ & $\mathrm{O}$ & $\mathrm{O}$ & $\triangle$ & $\mathrm{O}$ & $\mathrm{O}$ & $X$ & $\mathrm{O}$ & $\mathrm{O}$ & $\mathrm{O}$ & X & $\triangle$ & $\triangle$ & $X$ & $X$ \\
\hline M5 & $X$ & $X$ & X & $\triangle$ & X & X & $X$ & $X$ & $\mathrm{O}$ & $\mathrm{O}$ & $\mathrm{O}$ & $\triangle$ & $X$ & $\mathrm{O}$ & $X$ & $X$ \\
\hline M6 & $X$ & $\mathrm{O}$ & $\triangle$ & $\triangle$ & $\triangle$ & $\triangle$ & X & X & $X$ & $\mathrm{O}$ & $X$ & $\mathrm{X}$ & $\triangle$ & X & $X$ & $X$ \\
\hline M7 & $\mathrm{O}$ & $\mathrm{O}$ & $\mathrm{O}$ & $\triangle$ & $\triangle$ & X & $X$ & $X$ & $\mathrm{O}$ & $\mathrm{O}$ & $\mathrm{O}$ & $\triangle$ & X & $\triangle$ & $X$ & $X$ \\
\hline M8 & X & $\mathrm{O}$ & $\mathrm{O}$ & $\mathrm{O}$ & $\triangle$ & $X$ & $X$ & X & $\mathrm{O}$ & $\mathrm{O}$ & $\mathrm{O}$ & $\mathrm{O}$ & $\triangle$ & $\triangle$ & $X$ & $X$ \\
\hline M9 & $X$ & $\triangle$ & X & $\mathrm{O}$ & X & $\triangle$ & $X$ & $X$ & $\mathrm{O}$ & $\mathrm{O}$ & $\mathrm{O}$ & $\triangle$ & $\mathrm{O}$ & $\triangle$ & $X$ & $X$ \\
\hline Hal & $X$ & $\triangle$ & $\mathrm{O}$ & $\mathrm{O}$ & $X$ & X & $X$ & $X$ & $\mathrm{O}$ & $\mathrm{O}$ & $\mathrm{O}$ & $\mathrm{O}$ & X & $\mathrm{O}$ & $X$ & $X$ \\
\hline $\mathrm{Ha} 2$ & X & $\triangle$ & X & $\triangle$ & $X$ & $\triangle$ & $\triangle$ & X & $\mathrm{O}$ & $\mathrm{O}$ & $\mathrm{O}$ & $\mathrm{O}$ & $X$ & $\mathrm{O}$ & $X$ & $X$ \\
\hline Ha3 & $\mathrm{O}$ & $\mathrm{O}$ & $\triangle$ & $\mathrm{O}$ & $\triangle$ & X & $X$ & $X$ & $\mathrm{O}$ & $\mathrm{O}$ & $\mathrm{O}$ & $\triangle$ & $X$ & $\triangle$ & $X$ & $X$ \\
\hline Ha4 & $\mathrm{O}$ & $\triangle$ & $\mathrm{O}$ & $\triangle$ & $\triangle$ & $\mathrm{O}$ & $X$ & $X$ & $\mathrm{O}$ & $\mathrm{O}$ & $\mathrm{O}$ & $\triangle$ & $X$ & $\triangle$ & $X$ & $X$ \\
\hline Ha5 & $X$ & $\triangle$ & $\mathrm{O}$ & $\mathrm{O}$ & $X$ & X & $\mathrm{X}$ & X & $\mathrm{O}$ & $\mathrm{O}$ & $\mathrm{O}$ & $\mathrm{O}$ & $X$ & $\triangle$ & $X$ & $\mathrm{X}$ \\
\hline Ha7 & $X$ & $\mathrm{O}$ & $\triangle$ & $\triangle$ & $X$ & $\triangle$ & $\triangle$ & $X$ & $\mathrm{O}$ & $\mathrm{O}$ & $\mathrm{O}$ & $\triangle$ & $X$ & $\mathrm{O}$ & $X$ & $\mathrm{X}$ \\
\hline Ha8 & $\mathrm{O}$ & $\mathrm{O}$ & $\mathrm{O}$ & $\mathrm{O}$ & $X$ & $\mathrm{X}$ & X & X & $\mathrm{O}$ & $\mathrm{O}$ & $\mathrm{O}$ & $\mathrm{O}$ & $X$ & $\triangle$ & X & $\mathrm{X}$ \\
\hline Ha9 & X & $\triangle$ & $\mathrm{O}$ & $\triangle$ & $\triangle$ & O & $\triangle$ & X & $\mathrm{O}$ & $\mathrm{O}$ & $\mathrm{O}$ & $\triangle$ & $X$ & $\triangle$ & $X$ & $X$ \\
\hline Ha10 & $\mathrm{O}$ & $\triangle$ & $\mathrm{O}$ & $\mathrm{O}$ & X & $\triangle$ & 0 & $\triangle$ & $\mathrm{O}$ & $\mathrm{O}$ & $\mathrm{O}$ & $\mathrm{O}$ & $X$ & $\mathrm{O}$ & X & X \\
\hline Hall & X & $\triangle$ & $\triangle$ & $\triangle$ & $\triangle$ & $\mathrm{X}$ & $X$ & $\mathrm{X}$ & $\mathrm{O}$ & $\mathrm{O}$ & $\mathrm{O}$ & $\mathrm{O}$ & $X$ & $\triangle$ & X & X \\
\hline Ha12 & $X$ & $\triangle$ & $\triangle$ & $\mathrm{O}$ & $\triangle$ & $\mathrm{O}$ & $\triangle$ & X & $\mathrm{O}$ & $\mathrm{O}$ & $\mathrm{O}$ & $\mathrm{O}$ & $X$ & $\triangle$ & $X$ & X \\
\hline $\mathrm{Hb} 2$ & $X$ & $\mathrm{X}$ & $X$ & $\mathrm{O}$ & X & O & $X$ & $\mathrm{X}$ & $\mathrm{O}$ & $\mathrm{O}$ & $\mathrm{O}$ & $\mathrm{O}$ & $\triangle$ & O & $X$ & $\mathrm{X}$ \\
\hline $\mathrm{Hb} 3$ & $X$ & $\triangle$ & $\triangle$ & $\triangle$ & X & $\triangle$ & $\mathrm{O}$ & X & $\mathrm{O}$ & $\mathrm{O}$ & $\mathrm{O}$ & $\triangle$ & $\mathrm{O}$ & $\mathrm{O}$ & $X$ & $\mathrm{X}$ \\
\hline $\mathrm{Hb} 4$ & X & $\triangle$ & $\triangle$ & $\triangle$ & $\mathrm{X}$ & $\triangle$ & $\mathrm{O}$ & X & $\mathrm{O}$ & $\mathrm{O}$ & $\mathrm{O}$ & $\mathrm{O}$ & $\triangle$ & $\mathrm{O}$ & $X$ & $\mathrm{X}$ \\
\hline $\mathrm{Hb} 5$ & X & $\triangle$ & $\triangle$ & $\mathrm{O}$ & $\mathrm{X}$ & $\triangle$ & O & $\mathrm{X}$ & $\mathrm{O}$ & $\mathrm{O}$ & $\mathrm{O}$ & $\mathrm{O}$ & O & $\triangle$ & $\mathrm{O}$ & $\mathrm{X}$ \\
\hline Hb6 & $X$ & $\triangle$ & $X$ & $\mathrm{O}$ & $X$ & $\triangle$ & $\triangle$ & $\mathrm{X}$ & $\mathrm{O}$ & $\mathrm{O}$ & $\mathrm{O}$ & X & $\triangle$ & $\mathrm{O}$ & $\mathrm{O}$ & X \\
\hline
\end{tabular}

는 부분과 동해 남부의 해류를 볼 수 있도록 Fig. 6 에 별도로 나타내었다. 동해 중앙부에서의 대마난류 의 분지에 관해서는 대마난류 부분에서 다시 언급하 기로 하고 대한해협을 통과하기 바로 직전과 직후의 대마난류의 표현에 대해서 조사하였다.

일반적으로 해수 수송량의 계절 변화가 있지만 대 한해협 중 우리나라에 가까운 서수도를 통해서 대마 난류가 동수도에 비해 3 배 정도 더 큰 수송량을 보 인다고 보고되었다(e.g., 이석우, 1966a; Isoda and Yamaoka, 1991; Gordon et al., 2002). 대한해협을 지 나는 대마난류의 기원은 주로 쿠로시오해류로부터 $30.5^{\circ} \mathrm{N}, 129^{\circ} \mathrm{E}$ 해역에서 갈라진 것이며(Nitani, 1972; Lie et al., 1998; Teague et al., 2003), 부분적으로는 제주해협을 지나온 대만난류가 기원이 된다(Chang et al., 2000; Lie et al., 2000). 그 양을 비교하면 각각 $80 \%$ 와 $20 \%$ 정도를 차지한다(Teague et al., 2005).

따라서 교과서 해류도는 대한해협 서수도와 동수도 를 지나가는 해류를 각각 표현하여야 할 것으로 판
단된다. 이러한 기준으로 $\mathrm{C} 1$ 을 만들었으며 Table 3과 같이 분석하여 제시하였다. Table 3 은 27종 교과서 중에서 평균 해류도를 제시한 25 종의 교과서만 선택 하여 분석하였고, $\mathrm{Ha} 6$ 교과서는 한 개의 해류도도 제시하고 있지 않아서 제외하였다. 또한 $\mathrm{Hb} 1$ 교과서 는 평균 해류도 대신 계절해류도를 제시하고 있는데 다른 해류도와 상이한 점이 많이 발견되어서 분석에 서 제외하였다. 각 분석 항목에 적합한 경우 진한 회 색, 일부 적합하거나 일부 부적합할 경우를 중간 회 색, 그리고 부적합한 경우를 연한 회색으로 표현하였 고, 각각은 $\bigcirc, \triangle, \times$ 의 기호도 같이 표시하였다. 해 류가 대마도에 도착하기 전에 분기하여 대마도의 서 수도와 동수도로 각각 나뉘어 들어가는 경우를 적합 한 경우로 판단하여 진한 회색으로 표현하였다. 이에 해당하는 교과서는 3종(M1, M4, M7)의 중학교 교과 서, 4종 $(\mathrm{Ha} 3, \mathrm{Ha} 4, \mathrm{Ha} 8, \mathrm{Ha} 10)$ 의 고등학교 과학 교 과서가 있었다. 대마난류가 대마도 전에 분기하지 않 는 경우는 부적합 경우로 보고 연회색으로 표현하였 

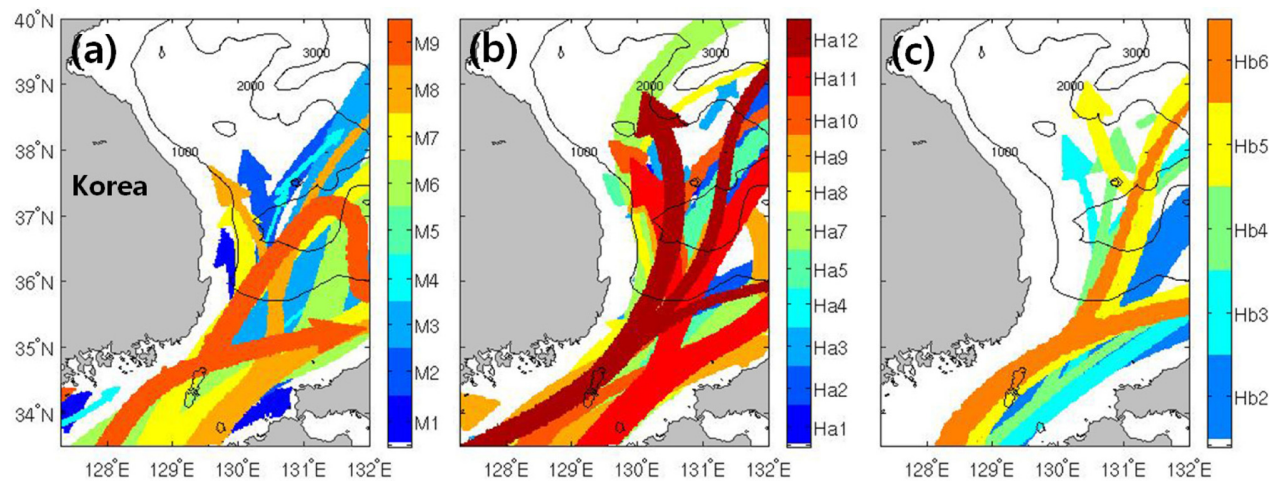

Fig. 6. The flow patterns of the East Korea Warm Current off the east coast of Korea from the textbooks of (a) middle school science, (b) high school science, and (c) high school earth science I.

는데 지구과학 I 교과서의 경우는 모두 부적합하였다. 이와 같이 대한해협 부근의 해류가 복잡한 양상을 띠고 있지만 분기와 관련된 해류는 대마도 이전에 동수도와 서수도로 분기되어 동해로 유입하는 것으 로 해류를 해류도에 표현하는 것이 바람직하다고 판 단된다.

Fig. 6은 대한해협 부근과 우리나라 동해안 해류를 자세히 볼 수 있도록 나타낸 것으로 교과서 해류도 의 오류를 쉽게 볼 수 있다. 해류가 대마도 이전에 분기하는 모습으로 표현한 교과서 중 대마난류가 대 마도와 만나기 전부터 분기되어 동해로 유입하는 모 습을 보인 교과서는 $\mathrm{M} 1, \mathrm{M} 4, \mathrm{Ha} 3, \mathrm{Ha} 4$ 의 4종이었 고, $\mathrm{M} 7, \mathrm{Ha} 8, \mathrm{Ha} 10$ 의 3종의 교과서는 해류가 대마 도와 만나며 분기하는 모습을 보였다. 나머지 교과서 는 대마도 이후에 분기하는 양상으로 표현하는 등 다양하게 표시하고 있었다. 전체 25 종 교과서의 $28 \%$ 만이 적절하게 나타내고 있었다.

\section{대한해협 통과 후 해류 분지}

대한해협에서 동해로 유입되는 대마난류 분지의 개 수와 형태를 서로 다르게 보는 견해가 많지만 그 동 안의 과학논문 결과들을 요약해 보면 크게 세 가지 의 분지로 나누어진다. 대마난류의 제 1 분지라 불리 는 일본 연안을 따라 흐르는 근해 분지(Nearshore Branch, NB), 제 3 분지로 불리는 한국 연안을 따라 흐르는 동한난류(East Korea Warm Current, EKWC) 가 있고, 대마난류의 근해 분지와 동한난류 사이에 연안에서 떨어져 흐르는 동한난류의 분지인 제 2 분 지라 불리는 외해 분지(Offshore Branch, OB)가 존재 한다(e.g., Suda and Hidaka, 1932; Kawabe, 1982;
Katoh, 1994; Lee and Niiler, 2005). 이 중 제 2분지 는 시간적으로 공간적으로 변동성이 매우 크고 동한 난류도 계절변동과 더불어 어떤 해에는 발생하지 않 았다고 보고되는 등 경년변동도 크게 나타난다(Kim and Legeckis, 1986). 대한해협에서의 수송량은 계절 에 따라 변화하며 여름철에 최대, 겨울철에 최소가 된다(Miyazaki, 1952; Yi, 1966; Chang et al., 2004). 최근의 연구에 의하면 대한해협을 통과하는 대마난류 의 수송량과 상대와도(relative vorticity)가 세 가지 분지의 형태와 관련이 깊다고 보고되었다(Kawabe, 1982; Lee and Niiler, 2010).

대마도 전에 분기하지 않고 동해로 유입한 대마난 류에 대하여 대한해협을 통과한 후 해류의 분기 모 습을 조사한 결과, Table 4에 제시한 바와 같이 대마 난류가 대한해협 동수도 혹은 서수도로 진행하지 않 고 대마도 위로 바로 관통하도록 해류를 표시한 교 과서는 중학교 M3, M6 교과서와 고등학교 $\mathrm{Ha} 2$, $\mathrm{Ha} 7, \mathrm{Ha} 12$ 교과서, 지구과학 $\mathrm{Hb} 5, \mathrm{Hb} 6$ 교과서가 있 었다. 이러한 문제는 해류도를 제시하고 있는 원래의 출처와 참고 문헌에서는 발견되지 않는 현상으로 교 과서 삽화를 작성할 때 해양학적인 지식이 없는 일 러스트레이터나 교과서 편집진의 부주의 혹은 기타 다른 사유로 발생하였을 가능성이 높다. 또한 M9, $\mathrm{Ha} 9$ 교과서의 경우는 대한해협의 서수도로만 진행하 도록 표현하였고, 나머지 9종의 교과서(M2, M5, $\mathrm{M} 8, \mathrm{Ha} 1, \mathrm{Ha} 5, \mathrm{Ha} 11, \mathrm{Hb} 2, \mathrm{Hb} 3, \mathrm{Hb} 4$ )가 대한해협 동수도로만 진행하는 것으로 나타내고 있었다.

최근의 연구 결과에 의하면 대만해협을 지나 대만 북쪽으로 진행한 쿠로시오해류의 지류(Beardsley et al., 1985; Fang et al., 1991)와 대만 남쪽에서 대륙 
Table 4. Classification of the secondary school textbooks with respect to the bifurcation of the Tsushima Warm Current near the Tsushima Island in the Korea Strait

\begin{tabular}{cccccc}
\hline & Items & \multicolumn{2}{c}{ Prior to the Tsushima Island } & \multicolumn{3}{c}{ After the Tsushima Island } \\
\cline { 2 - 6 } Textbooks & $\begin{array}{c}\text { Bifurcated far from } \\
\text { the Tsushima Island }\end{array}$ & $\begin{array}{c}\text { Biffurcated by the } \\
\text { Tsushima Island }\end{array}$ & $\begin{array}{c}\text { Passed right over the } \\
\text { Tsushima Island }\end{array}$ & $\begin{array}{c}\text { To the western } \\
\text { channel only }\end{array}$ & $\begin{array}{c}\text { To the eastern } \\
\text { channel only }\end{array}$ \\
\hline $\begin{array}{c}\text { Middle school } \\
\text { Science }\end{array}$ & M1, M4 & M7 & M3, M6 & M9 & M2, M5, M8 \\
\hline $\begin{array}{c}\text { High school } \\
\text { Science }\end{array}$ & Ha3, Ha4 & Ha8, Ha10 & Ha2, Ha7, Ha12 & Ha9 & Hal, Ha5, Ha11 \\
\hline $\begin{array}{c}\text { High school } \\
\text { Earth Science I }\end{array}$ & - & Hb5, Hb6 & - & Hb2, Hb3, Hb4 \\
\hline
\end{tabular}

사면을 따라 북동진하는 쿠로시오해류의 본류가 대마 난류를 이루어 대마난류는 대만난류와 쿠로시오해류 에서 기원되었다고 볼 수 있다(Pang et al., 1994). 따 라서 이러한 연구들을 종합하여 연구 영역의 해류를 표시한다면, 대마난류는 대마도 이전에 분기되어 서 수도와 동수도를 통과하고, 통과한 후 각각 한국 동 해안을 따라 북상하는 동한난류와 북동쪽으로 향하는 대마난류의 분지로 나뉘어야 할 것이다. 또한 대한해 협의 동수도를 통과한 해류는 일본 연안을 따라 북 상하도록 표현하는 것이 바람직하다고 판단된다.

\section{동한난류 연안주축거리}

동한난류는 대한해협의 서수도로 유입한 대마난류 가 한반도 동쪽 해안을 따라 북상하는 흐름이다(e.g., 이석우, 1992; 한국해양학회, 2005; Tanioka, 1968; $\mathrm{Lie}, 1984)$. 전 계절에 걸쳐 존재하나(Kawabe, 1982), 계절 변동을 보이고, 가을에 수송량이 가장 많다 (Chang et al., 2004). 북상하는 동한난류 주축의 연 안으로부터의 거리는 계절 변동을 보이는데 다른 계 절에 비해 여름철에는 연안으로부터 보다 멀리 외해 로 떨어져서 북상한다. 이는 다른 여러 요인들이 있 지만 여름철 연안을 따라 남하하는 북한한류의 강화 와 관련이 있는 것으로 보고되었다(Lie, 1984).

Fig. 7은 각 교과서에 실려 있는 동한난류와 대마 난류에 대한 해류도를 나타낸 것이다. 교과서 해류도 와 비교하기 위하여 대표적인 과학논문(Lee and Niiler, 2005; Mooers et al., 2006)이 제시하고 있는 해류도와 국립해양조사원(KHOA; Korea Hydrographic and Oceanographic Administration) 홈페이지에 있는 해류도(국립해양조사원, 2010)를 선택하였다. Fig. 7d 에 표시한 바와 같이 과학논문에 실려 있는 동한난 류는 교과서 해류도에 비해 상대적으로 동해안에 가
깝게 근접하여 북상하는 것으로 표시되어 있다. 중학 교 과학 교과서의 경우 동한난류의 주축거리가 통일 되어 있지 않고 $130-132^{\circ} \mathrm{E}$ 범위에서 다양한 경도로 북상하는 것으로 나타내고 있고(Fig. $7 \mathrm{a}$ ), 고등학교 과학 교과서는 중학교 교과서에 비해 상대적으로 많 은 교과서가 연안가까이에 동한난류를 표시하고 있었 다(Fig. 7b). 지구과학 I 교과서의 경우에는 울릉도를 관통하거나 울릉도 동쪽에서 북동진하는 것으로 표시 하고 있어서 실제 동한난류의 북상과 유사하지 않은 양상을 보였다(Fig. 7c). Fig. 8a에 제시한 M5와 $\mathrm{Hb} 2$ 교과서는 동한난류가 동해안을 따라 북상하지 않고 울릉도 동쪽 외해로 북동진하는 것으로 표시한 대표 적인 사례로 적절하지 않다고 판단된다. 이 해류도로 학습한 대부분의 학생들은 우리나라 동해안 가까이에 는 난류가 없는 것으로 인지할 수 있다. 북상하는 동 한난류의 연안으로부터의 주축거리는 해류를 해류도 에 표현하는 가장 기본적인 요소들 중 하나로서 앞 으로 중요하게 다루어져야 하고 과학적 지식에 입각 하여 평균적인 양상을 표시하여야 할 것이다.

따라서 Table 3의 $\mathrm{C} 2$ 에 동한난류가 연안으로부터 얼마나 떨어져 북상하고 있는지를 분석항목으로 설정 하였다. 동한난류가 북상하다가 이안하기 전인 $37^{\circ} \mathrm{N}$ 를 기준으로 설정하여 연안으로부터의 주축거리를 계 산하였다. Fig. $8 \mathrm{~b}$ 에 연안으로부터의 거리에 대한 교 과서별 주축거리의 빈도수를 나타내었으며 중학교, 고등학교 과학 교과서, 지구과학 I 과정은 각각 진한 회색, 중간회색, 연회색으로 표현하였다. 각 교과서의 기호도 도표 안에 같이 제시하였다. 각 계급 안에서 의 순서는 연안으로부터의 주축거리의 함수로 표현하 였다. 즉 같은 계급 안에서 아래쪽에 표기한 교과서 일수록 연안으로부터의 거리가 가깝다. 연안으로부터 의 거리가 $35-45,45-55,55-65 \mathrm{~km}$ 인 세 구간에서의 

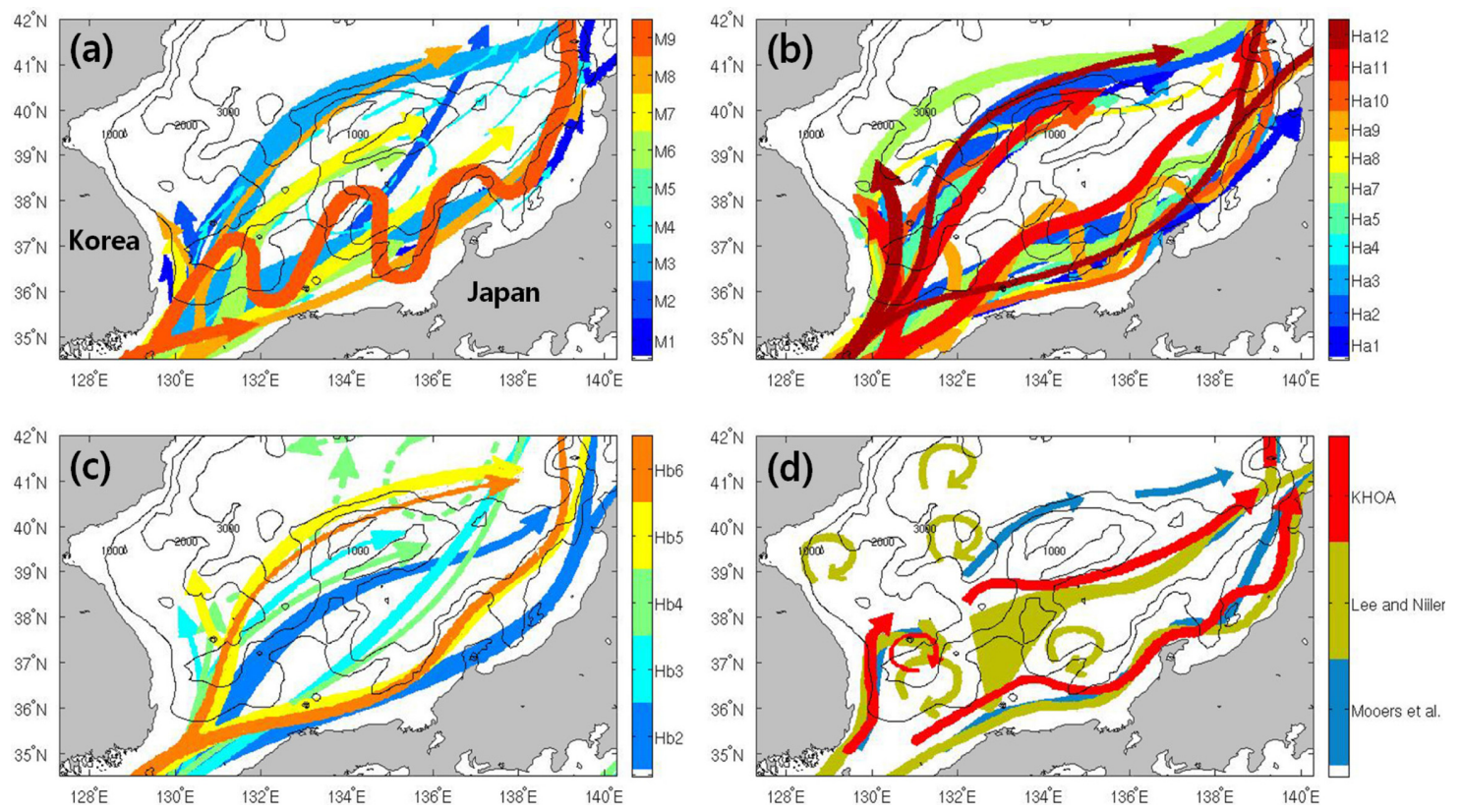

Fig. 7. The maps of the East Korea Warm Current and the Tsushima Warm Current in the textbooks from (a) middle school science, (b) high school science, (c) earth science I, and (d) some of research papers.
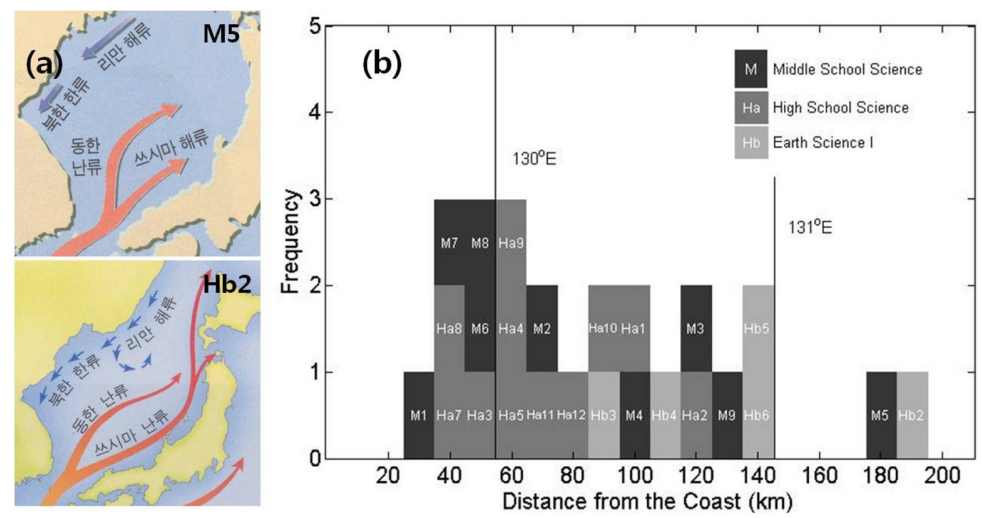

Fig. 8. (a) Examples of flow patterns of the East Korea Warm Current in the M5 and Hb2 textbooks and (b) the frequency histogram of the distance from the coast of EKWC along the zonal line of $37^{\circ} \mathrm{N}$, where the dark, medium, weak gray colors represent the textbooks of middle school science, high school science, and earth science I, respectively.

교과서가 각각 3 종으로 가장 높았다. Fig. $8 \mathrm{a}$ 에 나타 낸 바와 같이 M5 교과서의 주축거리는 $180 \mathrm{~km}$, $\mathrm{Hb} 2$ 교과서는 $190 \mathrm{~km}$ 정도로 다른 교과서에 비해 특히 먼 거리에서 동한난류가 북상하도록 표현하고 있었다. M5과 $\mathrm{Hb} 2$ 의 해류도가 위치상으로는 대마난 류의 제 2분지를 표시한 듯 보이지만 해류 옆에 ‘동 한난류'로 표시한 것으로 유추해보면 분명한 오류임 을 알 수 있다. 초기 인공위성 적외선 영상 분석을
통해 동한난류가 1981년 봄철에는 발생하지 않았다 고 보고한 논문도 있었으나(Kim and Legeckis, 1986 ) 이 외의 모든 연구 결과는 경년변동이 있지만 동한난류의 존재를 확인해주고 있고, 북상하는 난류 의 시차는 있지만 매년 발생하는 것으로 인정하고 있다(Chang, 2004).

$\mathrm{C} 2$ 항목에 대해 평가 결과를 세 단계로 분류하여 Table 3에 제시하였다. 동한난류가 이안하기 전 위도 
인 $37^{\circ} \mathrm{N}$ 에 위치한 연안 $\left(129.4^{\circ} \mathrm{E}\right)$ 을 기준으로 하였고, 기존의 과학 논문들의 결과를 바탕으로 동한난류가 동해 수심 $1000 \mathrm{~m}$ 가 시작되는 $130^{\circ} \mathrm{E}$ 이내로 북상하 는 경우를 적합하다고 판단하여 Table 3에서 진한 회 색으로 표현하였다. 중학교 과학 교과서인 M1, M6, $\mathrm{M} 7, \mathrm{M} 8$ 과 고등학교 과학 교과서인 $\mathrm{Ha} 3, \mathrm{Ha} 7, \mathrm{Ha} 8$ 이 이에 해당하였다. 동해 연안으로부터 동한난류의 북상축이 $130^{\circ} \mathrm{E}$ 이상 $131^{\circ} \mathrm{E}$ 이하의 범위에서 떨어져 북상하는 경우 일부 적합하다 판단하여 중간회색으로 표시하였고 이에 해당하는 교과서는 총 16 종이며 중 학교 과학 교과서 중 $\mathrm{M} 2, \mathrm{M} 3, \mathrm{M} 4, \mathrm{M} 9$, 고등학교 과학 교과서 중 $\mathrm{Ha} 1, \mathrm{Ha} 2, \mathrm{Ha} 4, \mathrm{Ha} 5, \mathrm{Ha} 9, \mathrm{Ha} 10$, $\mathrm{Ha} 11, \mathrm{Ha} 12$, 지구과학 I 교과서 중 $\mathrm{Hb} 3, \mathrm{Hb} 4, \mathrm{Hb} 5$, $\mathrm{Hb} 6$ 가 이 부류에 속하였다. 나머지 $131^{\circ} \mathrm{E}$ 이상 되는 위치에서 북상하는 것으로 제시한 교과서는 부적합하 다고 판단하여 연회색으로 표시하였고 $\mathrm{M} 5, \mathrm{Hb} 2$ 의 2 종이 이에 해당되었다.

\section{동한난류 이안 및 북상한계}

대한해협을 통과하여 한반도 동해안을 따라 북상한 동한난류는 $37-38^{\circ} \mathrm{N}$ 부근(Lee and Niiler, 2010)에서 북한한류와 만나 극전선을 형성하며 더 이상 해안을 따라 북상하지 않고 동쪽으로 방향을 바꾸어 멀어지 면서 연안으로부터 이안한다(Lie, 1984). Fig. 7의 해 류도는 동한난류의 북단을 화살표로 표시한 경우와 북쪽으로 향하는 화살표 없이 곡선으로 동쪽을 향하 여 이안하여 북동쪽으로 흐르는 경우, 또는 일부 북 상하고 일부 동쪽으로 흐르도록 동한난류를 분기하여 표현한 경우로 크게 두 가지로 표현하고 있다.

Table 3의 분석항목 $\mathrm{C} 3$ 에 대하여 동한난류가 129$130^{\circ} \mathrm{E}$ 서쪽과 $37^{\circ} \mathrm{N}$ 에서 $38^{\circ} \mathrm{N}$ 사이에서 동쪽으로 이 안하는 경우를 적합한 것으로 판단하여 진한 회색으 로 표현하였다. 동한난류의 주축은 $37-38^{\circ} \mathrm{N}$ 사이에서 이안하나 일부는 계속 동해 연안을 따라 북상하여 $38-40^{\circ} \mathrm{N}$ 에 난류성 소용돌이를 형성하기도 한다. 따라 서 $38^{\circ} \mathrm{N}$ 이북으로 북상하게 표현한 경우를 일부 적 합으로 판단하여 중간회색으로 표현하였고, $37^{\circ} \mathrm{N}$ 이 남에서 이안한 경우는 부적합한 경우로 분류하여 연 한회색으로 표시하였다.

동한난류의 북상한계는 $131^{\circ} \mathrm{E}$ 서쪽 영역에서 동한 난류 화살표 끝이 위치한 위도와 화살표 표시가 없 는 경우는 해당 영역 내에서 곡선의 위도로 정하였 다. Fig. 9는 각 교과서별로 동한난류의 북상한계를

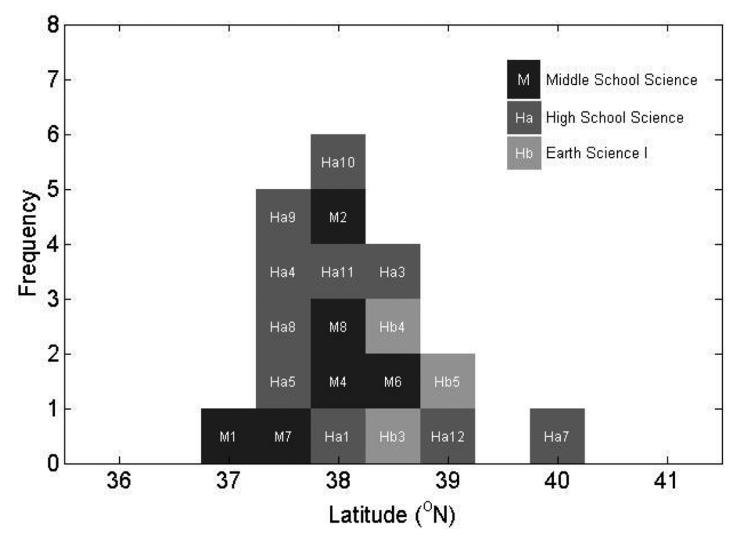

Fig. 9. The frequency histogram of the northern limits of the north-eastward propagating East Korea Warm Current as a function of latitude.

위도로 산출하고 위도에 따른 빈도수를 표현한 것이 다. 해당 영역 바깥에서 북동진한 경우는 분석 대상 에서 제외하였다. $38^{\circ} \mathrm{N}$ 부근까지 북상하는 경우가 6 종으로 가장 많았고, $37.5^{\circ} \mathrm{N}$ 부근까지 북상하는 경우 는 4종으로 빈도수가 두 번째로 많았다. $\mathrm{Ha}$ 는 25 종 교과서 중 동한난류의 북상거리가 가장 먼 $40^{\circ} \mathrm{N}$ 까지 진행하도록 표현되었다.

따라서 $\mathrm{C}$ 에서 적합한 경우는 중학교 과학 교과서 4종(M2, M4, M7, M8), 고등학교 과학 교과서 7종 (Ha1, Ha4, Ha5, Ha8, Ha9, Ha10, Ha11)으로 총 11 종이다. 일부 적합한 경우는 중학교 과학 교과서 1종 (M6), 고등학교 과학 교과서 3종(Ha3, $\mathrm{Ha} 7, \mathrm{Ha} 12)$, 지구과학 I 교과서 3종 $(\mathrm{Hb} 3, \mathrm{Hb} 4, \mathrm{Hb} 5)$ 으로 총 7종 이다. $37^{\circ} \mathrm{N}$ 이남에서 이안한 경우인 M1은 부적합한 경우로 판단하였다.

\section{일본 연안을 따른 대마난류}

대마난류의 제 1 분지는 대한해협의 동수도로 유입 되어 일본 혼슈의 북쪽 해안에서 $200 \mathrm{~m}$ 보다 얕은 곳 을 따라 북동쪽으로 진행하는 흐름이다(e.g., Lee et al., 1997). 제 1 분지는 특히 봄부터 여름사이에 강하 게 발달하며(Kawabe, 1982) 겨울철부터 이듬 해 봄 까지는 일본연안에서 보다 멀리 떨어져 흐르는 분지 가 발달한다. Fig. 7에서 볼 수 있듯이 교과서 해류 도는 대마난류의 제 1 분지를 다양하게 나타내고 있 다. 대마난류 제 1 분지의 계절변화와 경년변화에 관 한 기존의 연구들을 종합해보면 교과서 해류도는 해 류의 평균적 양상을 표현하여야 하므로 제 1 분지는 


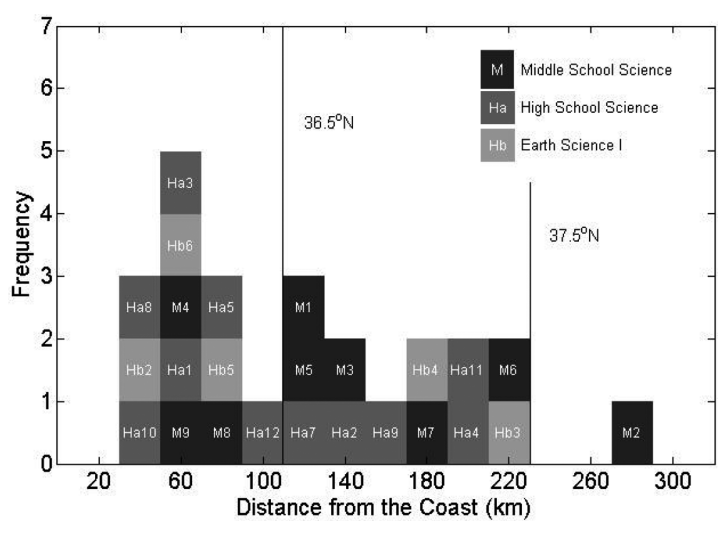

Fig. 10. The frequency histogram of north-south distances of the 1st-branch Tsushima Warm Current from the Japanese coast.

일본 연안을 가까이 붙어서 쓰가루해협 부근까지 북 동진하는 것이 바람직하다고 판단된다. 과학논문에서 제시하고 있는 대마난류 제 1 분지는 Fig. $7 \mathrm{~d}$ 와 같이 연안에 매우 근접한 상태로 진행하고 있다(e.g., Lee and Niiler, 2005). 하지만 교과서 대마난류의 제 1 분 지는 공간적으로 매우 다양하게 분포하고 있고 일본 연안으로부터 상당히 떨어져 있는 경우도 많이 발견 된다.

따라서 본 연구에서는 일본 연안에 얼마나 가깝게 붙어있는지를 정량적으로 나타내기 위하여 경도 13 $5^{\circ} \mathrm{E}$ 의 해안선을 기준으로 북동진하는 대마난류가 지 나가는 평균 위도를 각 교과서 해류도별로 산출하고, Fig. 10 에 분석 결과를 제시하였다. $135^{\circ} \mathrm{E}, 35.5^{\circ} \mathrm{N}$ 연 안으로부터 북쪽 방향으로 $60 \mathrm{~km}$ 떨어져 있는, 즉 위도 $36^{\circ} \mathrm{N}$ 지점에서 대마난류가 북동진하도록 제시 한 교과서가 5종으로 빈도수가 가장 높았다.

Table 3의 $\mathrm{C} 4$ 분석항목에서는 경도 $135^{\circ} \mathrm{E}$ 를 기준 으로 제 1 분지의 연안 $\left(35.5^{\circ} \mathrm{N}\right)$ 으로 부터의 위도방향 거리가 $1^{\circ}$ 이내 $\left(36.5^{\circ} \mathrm{N}\right.$ 이남)에서 진행할 경우를 적 합하다 판단하였고, 중학교 과학 교과서 3 종 $(\mathrm{M} 4$, $\mathrm{M} 8, \mathrm{M} 9)$, 고등학교 과학 교과서 6종(Ha1, $\mathrm{Ha} 3$, $\mathrm{Ha} 5, \mathrm{Ha} 8, \mathrm{Ha} 10, \mathrm{Ha} 12$ ), 지구과학 I 교과서 3종 $(\mathrm{Hb} 2, \mathrm{Hb} 5, \mathrm{Hb} 6)$ 으로 총 12종이 이에 해당되었다. $1-2^{\circ}$ 사이의 거리 $\left(36.5-37.5^{\circ} \mathrm{N}\right)$ 에 있는 경우는 총 12 종으로 중학교 과학 교과서 5종(M1, M3, M5, M6, $\mathrm{M} 7)$, 고등학교 과학 교과서 5 종( $\mathrm{Ha} 2, \mathrm{Ha} 4, \mathrm{Ha}$, $\mathrm{Ha} 9, \mathrm{Ha} 11)$, 지구과학 I 교과서 2종( $\mathrm{Hb} 3, \mathrm{Hb} 4)$ 이 해 당하며 일부 부적합하다고 판단하여 중간회색으로 표
시하였다. 동해 중앙에 제 1 분지의 주축거리가 연안 으로부터 위도 $2^{\circ}$ 이상의 거리에 있는 경우는 부적합 하다 판단하여 연회색으로 표시하였고, M2가 이에 해당되었다. 적합하다고 판단되는 교과서는 12 종이지 만 실제로 일본 연안에 지속적으로 근접하여 북상하 도록 표시하여야 하는데 경도 $138^{\circ} \mathrm{E}$ 를 기준으로 보 면 많은 경우가 부적합하여 $\mathrm{Hb} 2$ 교과서와 같이 전체 적으로 대마난류 제 1 분지를 적합하게 표시한 교과 서는 극히 적었다.

\section{동해 중앙부에서의 대마난류}

동해 중앙부에는 극전선이 대략 $40^{\circ} \mathrm{N}$ 을 따라 동서 로 발달되어 있다(Kubota, 1990; Park et al., 2004). 이 전선대의 서쪽 끝과 동쪽 끝부분은 강한 계절변 동을 보이고 있어서(Park et al., 2007), 이 전선대와 연결되는 동한난류와 대마난류 역시 다양한 시공간적 변동성을 보인다. 한반도 동해안을 따라 북상하고 이 안한 동한난류는 표층에서 $40^{\circ} \mathrm{N}$ 부근에 존재하는 극 전선의 남쪽을 따라 쓰가루해협을 향해 북동진하여 대마난류를 이루는 주요한 성분이 된다. 이보다 더 남쪽에서는 대마난류의 제 2 분지에 해당하는 흐름이 공간적으로 복잡한 분포를 보이고 강한 계절변동과 경년변동을 나타낸다(e.g., Lee and Niiler, 2010). 대 마난류의 제 2분지는 대한해협 서수도를 통과한 후 (Lee et al., 1997), 울릉분지의 남동쪽에서 대륙붕을 따라 북동쪽을 향해 흐르는데(Hase et al., 1999), 이 는 해저지형의 영향을 많이 받음을 의미한다 (Kawabe, 1982). 이 분지는 봄부터 발달하여 가을까 지 이어지며(Hase et al., 1999) 대한해협에서 대마난 류의 속도와 수송량이 상당히 증가했을 때 나타난다 (Kawabe, 1982). 울릉분지 부근에서 큰 와류를 형성 하며 와류의 내부엔 반시계방향의 소용돌이가 형성된 다(e.g., Cho et al., 1990). 동해의 동쪽에서 북동방향 으로 흐르던 제 2 분지와 일본연안을 따라 북상하던 대마난류의 제 1 분지가 만나 쓰가루해협에서의 난류 의 일부가 태평양을 향하여 유출된다(Onish and Ohtani, 1997). Senjyu et al.(1999)가 제안한 동해 해 류모식도는 대만난류의 제 2분지를 제시하지 않은 데 반해, Lee and Niiler(2010)는 기존의 대마난류의 3분지설과 유사한 울릉소용돌이 형태(Ulleung eddy pattern), 관성경계류 형태(inertial boundary current pattern), 대마난류 형태(Taushima Warm Current pattern) 등 세 가지로 분류한 모식도를 제안하였다. 
Table 5. The number of the branches of the Tsushima Warm Current south of the subpolar front in the East Sea

\begin{tabular}{ccc}
\hline \hline The number of the branches & 2 branches & 3 branches \\
Textbooks & $\mathrm{M} 2, \mathrm{M} 3, \mathrm{M} 5, \mathrm{M} 9$ & $\mathrm{M} 1, \mathrm{M} 4, \mathrm{M} 6, \mathrm{M} 7, \mathrm{M} 8$ \\
\hline $\begin{array}{c}\text { Middle school Science } \\
\text { High school Science }\end{array}$ & $\mathrm{Ha1}, \mathrm{Ha} 2, \mathrm{Ha} 3, \mathrm{Ha} 5, \mathrm{Ha}$, Ha8, Ha10 & Ha4, Ha9, Ha11, Ha12 \\
High school Earth Science I & $\mathrm{Hb} 2, \mathrm{Hb} 3, \mathrm{Hb} 4, \mathrm{Hb} 5, \mathrm{Hb} 6$ & - \\
\hline
\end{tabular}

이와 같이 동해 중앙부에서의 해류는 계절변동성이 크고 경년변동이 커서 교과서에 하나의 해류도를 제 시하는 것은 어려움이 있으나, 대마난류의 제 1 분지 와 동한난류는 확실하게 표현하고 있어야 하며, 제 2 분지에 대해서는 직선에 가까운 모양으로 북동진하는 경우도 있고, 동해 남부를 크게 사행하는 형상도 나 타나는데, 해류도는 이 두 가지 중 어떤 경우이든 제 2분지에 해당하는 해류를 포함하고 있는 것이 바람직 하다고 판단된다.

우선 교과서에서 나타내고 있는 대마난류 분지를 조사하여 Table 5에서 교과서 해류도에 표현된 분지 의 형태를 크게 2 개의 분지로 표현한 경우와 3 개의 분지로 표현한 경우 두 가지로 나누었다. 동한난류와 제 2 분지의 구분은 대마난류의 서수도 유입 후 서로 갈라지는 위도가 $36^{\circ} \mathrm{N}$ 이하일 경우엔 제 2분지, 그 이상일 경우엔 동한난류로 분류하였다. 총 25 개의 해 류도 중 동해로 유입되는 해류의 분지를 3 개로 나누 어 표시한 경우가 중학교 과학 교과서에서는 총 5 종 (M1, M4, M6, M7, M8), 고등학교 과학 교과서에는 총 4종 $(\mathrm{Ha} 4, \mathrm{Ha} 9, \mathrm{Ha} 11, \mathrm{Ha} 12)$ 이 있었다. 보다 정확 하고 자세하게 제시되어야 할 지구과학 I 교과서에서 는 3 개의 분지로 표현한 교과서가 한 건도 없었다. 동해 중앙을 지나는 난류의 사행을 표현한 경우는 $\mathrm{M} 1, \mathrm{M} 9, \mathrm{Ha} 4, \mathrm{Ha} 9$ 로 총 4종인데 모두 사행을 지나 치게 강조하여 일본 연안을 따라 흐르는 제 1 분지를 제대로 표현하지 못하였다.

Table 3의 $\mathrm{C} 5$ 에서는 3 개의 분지로 표현하되 각 분 지의 특성을 잘 표현한 경우를 적합하다 판단하여 진한 회색으로 표시하였다. 3 개의 분지로 표현하였으 나 각 분지의 특성을 잘 반영하지 못한 경우나 2개 의 분지로 표현하였으나 사행을 표현한 경우는 일부 부적합하다 판단하여 중간회색으로, 2 개의 분지로 표 현한 경우는 부적합하다 판단하여 연회색으로 표시하 였다. 25 종의 교과서 중 3 개의 분지를 적절히 표시한 적합한 경우는 한 건도 없었으며 일부 적합한 경우 는 중학교 과학 교과서 중 5 종 $(\mathrm{M} 1, \mathrm{M} 4, \mathrm{M} 6, \mathrm{M} 7$,
$\mathrm{M} 8)$, 고등학교 과학 교과서 중 5 종(Ha3, $\mathrm{Ha} 4, \mathrm{Ha}$, $\mathrm{Ha} 11, \mathrm{Ha} 12)$ 이 있었으며, 지구과학 I 교과서 5종 전 체와 나머지 교과서들은 부적합한 것으로 분석되었다.

\section{해협을 통한 대마난류의 유출 및 재순환}

대한해협을 통과한 대마난류는 일본 연안을 따라 북상하다가 쓰가루해협 부근에서 일부는 계속 북상하 고 나머지 일부는 동쪽으로 진행하여 쓰가루해협을 통해 태평양으로 유출된다. 쓰가루해협을 통해 태평 양으로 나가는 대마난류와 계속 북상하는 대마난류의 비율은 계절에 따라 변동성이 크며 대마난류의 수송 량에 큰 영향을 받는데 쓰가루해협과 소야해협의 유 출량은 경년변동이 큰 것으로 보고되고 있다(Onishi and Ohtani, 1997). 그러나 매년 두 해협을 통한 태 평양과 오호츠크해로의 유출은 지속적으로 이루어지 고 있다.

Fig. 11은 각 교과서가 제시하고 있는 쓰가루해협 과 소야해협에서의 해류의 양상을 나타낸 것이다. 오 류가 발견되는 대표적인 사례를 들어보면, 중학교 M9교과서는 일본 연안을 따라 북상한 대마난류가 쓰 가루해협으로 약간의 유출도 없이 북상하고 있는 모 습을 보여주고 있고, 고등학교 $\mathrm{Hb} 6$ 의 경우는 쓰가루 해협으로는 유출되지 않고 모두 소야해협으로 나가는 것으로 표시하고 있다. 이에 반해 과학논문에서는 소 야해협과 쓰가루해협에서 일부 태평양으로 나가고 또 일부 북상하는 흐름을 적절히 표현하고 있다(Fig. 11d).

Table 3의 C6 분석 항목에서 쓰가루해협에서 유출 되는 대마난류와 일부 북상하는 모습을 잘 표현하였 는지에 대해 분석하였다. 해협을 통한 유출과 일부 북상하는 형상이 모두 잘 제시되었으면 적합하다고 판단하여 진한 회색 $(\bigcirc)$ 으로 표시하였고, $\mathrm{M} 1, \mathrm{M} 4$, $\mathrm{Ha} 4, \mathrm{Ha} 9, \mathrm{Ha} 12, \mathrm{Hb} 2$ 의 총 6종 교과서가 이 부류에 속하였다. 쓰가루해협 부근에서 대마난류가 태평양으 로 유출되지 않은 채 북상하거나 유출은 되지만 더 이상 북상하지 않는 경우엔 일부 적합하다고 판단하 

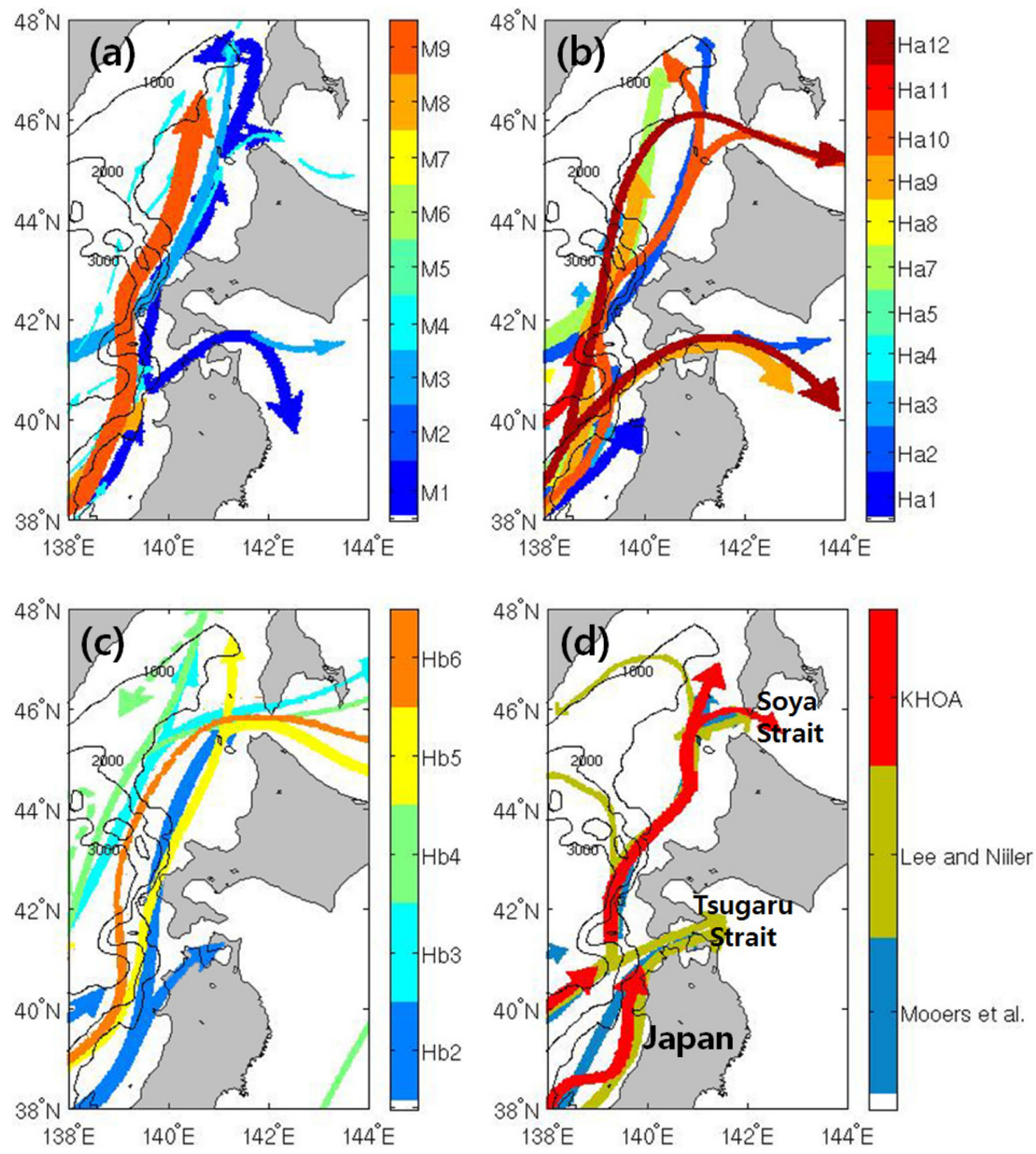

Fig. 11. The Tsushima Warm Current near the Tsugaru Strait and the Soya Strait, where the colors represent each textbook of (a) middle school science, (b) high school science, (c) earth science I, and (d) some of selected research papers, respectively.

여 중간 회색 $(\triangle)$ 으로 표시하였고, $\mathrm{M} 3, \mathrm{M} 6, \mathrm{M} 9$, $\mathrm{Ha} 2, \mathrm{Ha} 7, \mathrm{Ha} 10, \mathrm{Hb} 3, \mathrm{Hb} 4, \mathrm{Hb} 5, \mathrm{Hb} 6$ 으로 총 10 종 이 있었다. 마지막으로 쓰가루해협 부근에서 대마난 류가 유출되지 않으며 더 이상 북상하지도 않는 경 우는 연한 회색 $(\times)$ 으로 표시하였으며 이는 M2, M5, M7, M8, Ha1, Ha3, Ha5, Ha8, Ha11로 총 9종이 이 부류에 속하였다. 쓰가루해협을 통해 가장 많은 양의 대마난류수의 유출이 발생하는데도 불구하고, 쓰가루 해협에서의 대마난류 유출을 제대로 제시한 경우는 많지 않아 학습자들에게 오개념을 줄 수 있다. 해협 을 통한 해류의 표시는 동해 전체의 순환과 태평양 의 순환을 연결할 수 있는 고리이기 때문에 반드시 정확한 해류 벡터 표시를 제시하여야 학습자들의 이 해의 폭을 넓힐 수 있어야 한다.

쓰가루해협을 통과하지 않고 계속 북상한 대마난류
는 소야해협을 통해 오호츠크해로 일부 빠져나가고 나머지 일부는 다시 북상한 후 동해를 재순환한다 (Moriyasu, 1972). Table 3에서 C7을 통해 소야해협 에서의 대마난류 유출을 분석하였다. 대마난류가 소 야해협을 통해 일부 빠져나가고 나머지 일부는 북상 하는 경우를 정확히 표현된 경우는 적합하다 판단하 였고, 소야해협으로 유출되지 않은 채 북상하거나 소 야해협으로 대마난류가 모두 유출된 경우는 일부 적 합하다 판단하였다. 그 외에 대마난류가 소야해협까 지 북상하지 않은 경우 부적합한 것으로 간주하였다. 적합한 경우는 $\mathrm{M} 1, \mathrm{M} 4, \mathrm{Ha} 10, \mathrm{Hb} 3, \mathrm{Hb} 4, \mathrm{Hb} 5$ 의 총 6종, 일부 적합한 경우는 $\mathrm{M} 3, \mathrm{Ha} 2, \mathrm{Ha} 7, \mathrm{Ha} 9, \mathrm{Ha} 12$, $\mathrm{Hb} 6$ 로 총 6종, 부적합한 경우는 $\mathrm{M} 2, \mathrm{M} 5, \mathrm{M} 6, \mathrm{M} 7$, M8, M9, Ha1, Ha3, Ha4, Ha5, Ha8, Ha11, Hb2이며 총 13종이 발견되었다. 
동해의 전체 순환을 보면 북상하는 대마난류는 극 전선 이북에 있는 일본분지의 반시계방향의 순환과 더불어 재순환하는 양상을 보인다. 쓰가루해협을 통 과하지 않고 계속 북상한 대마난류는 소야해협에 도 달하기 전에 러시아 연안을 향하여 일부 북서진하여 러시아 연안에서 다시 남하하는 재순환하는 해류를 형성한다(Onishi and Ohtani, 1997). Fig. 11d의 Lee and Niiler(2005)는 이러한 흐름을 잘 표현하고 있는 반면, Fig. 11a, 11b, 11c에서 볼 수 있듯이 교과서 해류도는 이러한 재순환하는 해류를 전혀 표현하고 있지 않는 문제점을 드러내고 있다. 소야해협 부근에 서도 오호츠크해로 유출되는 해류 외에 약하지만 Fig. 11d의 Lee and Niiler(2005)가 표현한 바와 같이 북서진하여 러시아 연안에서 남하하여 재순환하는 흐 름이 존재한다. 이러한 재순환을 적합하게 표현한 교 과서는 Fig. 11a에 진한 푸른색으로 나타낸 중학교 M1 교과서가 유일하였다. 고등학교 $\mathrm{Ha} 10$ 교과서는 소야해협 위로 북상하는 해류의 방향이 북북서 방향 을 나타내고 있으나 다시 남쪽으로 재순환을 한다는 사실을 암시한다고 볼 수 있어 일부 적합하다 판단 하였고 Table 3 의 C8에 분석한 결과를 제시하였다.

동해의 $50^{\circ} \mathrm{N}$ 이북에는 동해와 오호츠크해를 연결 하는 타타르해협(Tatarskiy Strait)이 존재한다. 그러나 이 해협은 깊이가 매우 얕아서 해수의 유출입이 매 우 미약하다(Riser at al., 1999). 따라서 본 논문에서 는 언급하지 않기로 하고 분석항목에서 제외시켰다. 타타르 해협 남쪽 부분에서는 반시계방향의 순환이 형성되고 이로 인해 소야해협을 지나 북상한 대마난 류수는 동해로 재순환하며 리만해류의 형성에도 일부 영향을 미친다(Riser at al., 1999).

\section{동해북부의 리만해류}

동해에 존재하는 대표적인 한류는 리만해류(Liman Current)와 북한한류(North Korea Cold Current)가 있 으며, 리만해류는 러시아 연안을 따라 남하하는 흐름 이다. 타타르해협에는 1년 중 약 6 개월 동안 해빙이 존재하는데 11월 말에 형성되기 시작하여 이듬해 4 월이면 완전히 녹고, 해빙의 양은 대기와 해양환경에 따라서 경년변화가 심하다(Park et al., 2006). 봄철에 타타르 해협에서 빙하가 녹게 되면 온도가 매우 낮 고 염분이 낮은 해수가 형성되어 리만해류를 발생시 키는 원인이 된다(Martin and Kawase, 1998). 아무르 강(Amur River)은 연중 매우 적은 양의 담수를 타타
르해협으로 유출하는데, 적은 양이지만 이 담수는 겨 울철에 해빙을 형성할 때 기여하고, 이후 해빙이 녹 으면 리만해류 형성에 기여한다(Riser et al., 1999). 리만해류는 소야해협보다 약간 북쪽에서 시작하여 러 시아 블라디보스토크(Vladivostok)까지 흐르는데 여름 부터 이른 가을까지 연안 가까이에서 대륙붕을 따라 흘러 남하한다(Yarichin, 1980).

Table 3의 C9에서 리만해류를 제시한 경우는 적합 하다고 판단되어 진한 회색으로 표시하였으며 $\mathrm{M} 6$ 을 제외한 24종의 교과서가 이에 해당되었다. 리만해류 의 그 위치와 형태는 제시되었지만 리만해류라는 이 름을 표기하지 않은 경우는 $\mathrm{M} 2, \mathrm{M} 8, \mathrm{Ha} 5$ 교과서 3 종이 있었다. Fig. 12와 같이 M1, M3, M4, M9, $\mathrm{Ha} 2, \mathrm{Ha} 7, \mathrm{Ha} 9, \mathrm{Hb} 2$ 의 총 8 종의 교과서는 리만해류 가 남하하다 블라디보스토크까지 내려오지 못하고 반 시계 방향으로 재순환하는 모습을 나타내고 있었다. 특히 중학교 M1 교과서와 고등학교 $\mathrm{Ha} 9$ 교과서는 반시계방향으로 순환하는 두 개의 큰 환류를 표시하 고 있는데, 이는 계절적 변동이 심하여 기존의 과학 적 연구 결과를 기초로 한 해류도와 대치된다.

리만해류가 시작하는 위도를 조사한 결과, Fig. 13 과 같이 각 교과서는 $46^{\circ} \mathrm{N}$ 에서 $52^{\circ} \mathrm{N}$ 까지 다양하게 나타내고 있었다. $49^{\circ} \mathrm{N}$ 에서 시작하는 경우가 7종으로 가장 많았고, $47^{\circ} \mathrm{N}$ 에서 시작하는 경우가 5 종으로 빈 도수가 두 번째로 많았다. 또한 Fig. 12d에 제시한 3 가지 과학 논문의 경우도 $45-46^{\circ} \mathrm{N}$ 에서 리만해류가 시작하는 것으로 나타내어 상당한 차이가 있었다. Lee and Niiler(2005)의 경우는 인공위성 표층 뜰개 (satellite drifter) 자료를 활용하여 실제 그 해역에 뜰 개가 가지 않을 경우는 그 해역에 대한 해류를 알 수 있는 방법이 없기 때문에 자료 표본 수집의 오차 가 크며, $46^{\circ} \mathrm{N}$ 이북의 리만해류 부분은 자료 수집이 되지 않아 해류는 있으나 해류도에는 누락된 것으로 사료된다. 그러나 러시아 학계에서는 러시아연안에서 소야해협보다 약간 북쪽의 위도에서 시작하여 블라디 보스토크까지 남하하는 것으로 보고 있다(e.g., Yarichin, 1980). 따라서 소야해협보다 고위도인 $48^{\circ} \mathrm{N}$ 부근에서 리만해류가 시작하는 것으로 보는 것이 바람직할 것 으로 사료된다.

또한 리만해류의 러시아 연안으로부터의 거리를 조 사해보면, Fig. $12 \mathrm{~d}$ 의 과학논문들은 리만해류를 연안 에 매우 근접하여 남하하는 것으로 표현하고 있는데 반하여 교과서 해류도의 경우는 매우 다양하게 표시 

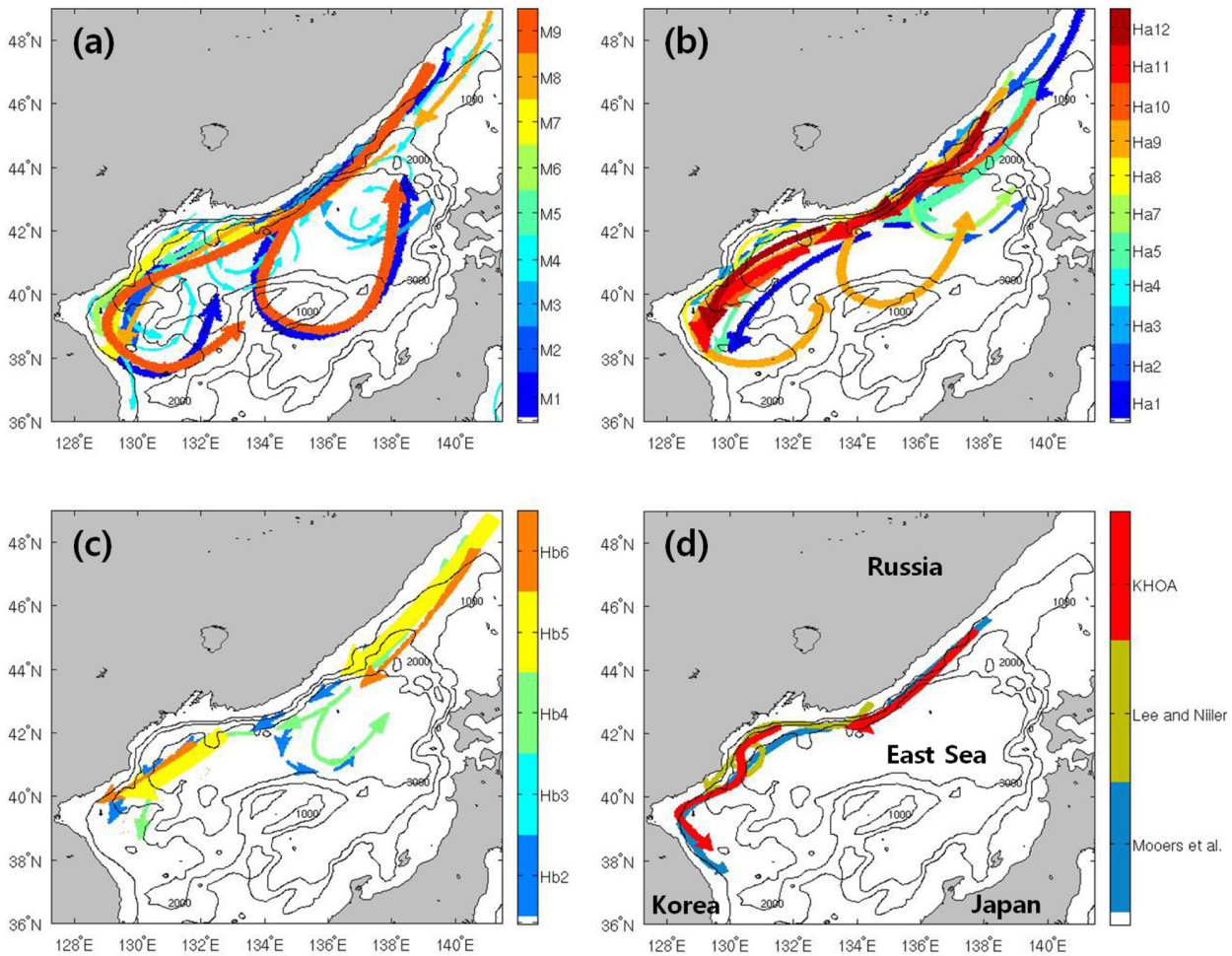

Fig. 12. Maps of the Liman Current and the North Korea Cold Current from the textbooks of (a) middle school science, (b) high school science, (c) earth science I, and (d) from some of research papers.

하고 있다. Fig. 12a에서 노란색으로 표시한 M7 교 과서의 경우는 $44^{\circ} \mathrm{N}$ 정도로 매우 낮은 위도에서 시 작하고 또 연안에서 가장 멀리 떨어져서 해류가 지 나가는 경로를 표시하여 리만해류에 관해서는 오류가 가장 큰 교과서로 분류된다. 또한 리만해류의 끝점도 다양하게 표현하고 있는데, 북한한류와 구분하기 위 하여 블라디보스토크 가까이 도달하기 전에 끝나도록 표시하는 것이 적절할 것으로 판단된다. 하지만 $\mathrm{Hb} 5$ 교과서의 경우는 $44^{\circ} \mathrm{N}$ 에서 이미 리만해류가 끝나는 것으로 표시되어 있어서 여름철 블라디보스토크까지 남하하는 해류를 적절히 표현하고 있지 못하였다. 따 라서 리만해류의 경우 한류의 시작점과 끝점, 연안으 로부터 떨어진 거리 등을 세밀하게 고려하여 정확하 게 해류도에 표시하여야 할 것이다.

\section{북한한류 및 심층해류}

북한한류는 북쪽에서 형성되어 남하해 온 리만해류 의 연속으로 북한연안을 따라 남하하기도 하고, 또는 블라디보스토크와 북한 연안 근처에서 형성되기도 한 다. 북한한류의 남하는 늦은 겨울 또는 이른 봄에 시

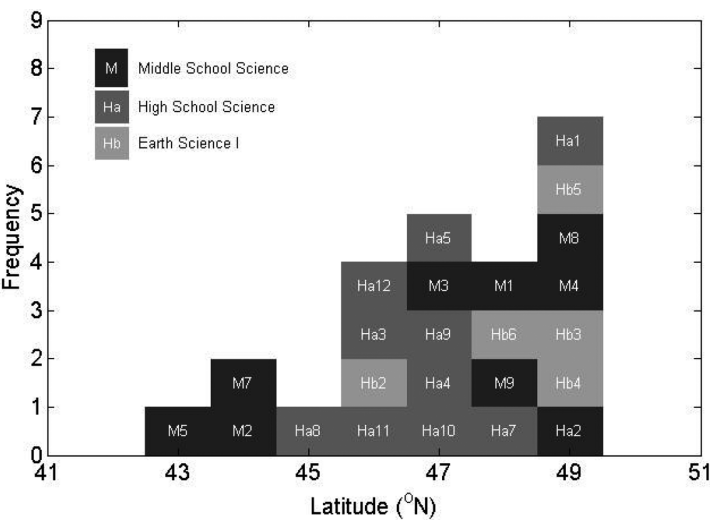

Fig. 13. Histogram of the latitudes where the Liman Current begins to be generated in the textbooks.

작되며 여름철에 $36^{\circ} \mathrm{N}$ 까지 남쪽으로 확장되고, 겨울 에는 북쪽으로 다시 쇠퇴하는 등 계절적으로 변동이 크다. 이 수온이 낮은 북한한류계수가 상대적으로 수 온이 높은 동한난류와 만나게 되면 동한난류는 북한 한류의 영향과 또 다른 요인들로 이안하게 된다( $\mathrm{Kim}$ and Kim, 1983; Toba et al., 1984). 해수면온도 영상 
에서 북한한류는 계속해서 표층으로 동해안을 따라 남하하는 양상을 보이기도 하고, 또는 동해안 중간에 이어지지 못하고 사라진 후 한반도 남동해안 근처에 서 다시 간헐적으로 표층에 나타나기도 한다.

평균 해류도를 제시한 25 종 모든 교과서에서 북한 한류를 제시하고 있으나, 연안으로부터의 거리와 남 하 범위 측면에서는 모든 교과서가 제각각으로 표현 하고 있었다. 중학교 M4 교과서는 $36^{\circ} \mathrm{N}$ 까지 남하하 는 양상을 보여주었으나, 나머지 거의 모든 교과서에 서 북한한류는 위도 $38^{\circ} \mathrm{N}$ 이북에서 끝나는 것으로 나타내고 있다. Fig. 12에서 확인할 수 있듯이 M1, $\mathrm{M} 4, \mathrm{M} 9, \mathrm{Ha} 4, \mathrm{Ha} 9$ 교과서는 연안을 따라 남하하는 흐름보다 반시계 방향으로 재순환하는 모습으로 나타 내고 있었다. M5와 $\mathrm{Ha} 10$ 의 경우는 실제 북한한류의 길이에 비해 지나치게 짧게 그렸으며, $\mathrm{M} 2$ 와 $\mathrm{M} 7$ 은 북한한류가 연안에서 상당히 떨어진 채로 흐르는 것 으로 표현하여 문제점이 발견되었다. $38^{\circ} \mathrm{N}$ 이남에서 는 표층 아래에서 남하하여 대한해협까지 북한한류수 가 발견되므로(Kim et al., 2006), 적어도 표층에서는 동한난류가 이안한 지점까지는 북한한류를 표시하여 야 할 것으로 판단된다.

심층해류는 일본분지에서 형성되며(Senjyu and Sudo, 1993; Seung and Yoon, 1995; Senjyu et al., 2005), 울릉분지와 독도 사이(Kim et al., 1991b; Chang et al., 2004), 또는 한국 대지(Korea Plateau) 를 통해서(Cho and Kim, 1994; Shin et al., 1998) $1200-2000 \mathrm{~m}$ 깊이에서 상대적으로 저염인 차가운 해 수를 남쪽의 울릉분지와 야마토분지(Yamato Basin)로 수송한다(Senjyu et al., 2005). 심층해류는 매우 좁은 범위의 온도와 염분을 가져서 제한적이나 해양에서 열염분순환을 일으키기 때문에 해양의 순환을 이해하 는 데 매우 중요하다.

심층해류가 제시된 교과서는 한 종도 없어 Table 3 의 $\mathrm{C} 16$ 에서는 모든 교과서가 부적합하다 판단되어 연회색으로 나타내었다. 표층해류는 표층뜰개 자료도 있고, 연구조사선에 의해서도 관측 기기를 이용하여 관측할 수 있어서 심층해류에 비해 상대적으로 관측 빈도가 높다. 중층해류도 $\mathrm{ARGO}$ 중층 부이자료를 이 용하면 해류를 계산해 낼 수 있다. 동해의 심층해류 와 관련하여 여러 학술논문들이 발표되어서(e.g., Chang et al., 2004; Senjyu et al., 2005) 동해에 존 재하는 심층해류에 대한 개괄적인 형상을 이해할 수 있게 되었다. 심층 해류에 대한 간략한 해류 모식도
도 제안되어 국내외적으로 현재 활용되고 있다 (Senjyu et al., 2005). 대서양에서 심층해류 관측은 지구온난화로 인한 해양의 변화를 가장 잘 이해하고, 미래의 기후 변화를 예측하는 매우 중요한 수단으로 인식되고 있다. 따라서 교과서에서도 심층해류를 점 선으로 표현하여 학생들이 동해의 전체적인 수직 순 환에 대해서도 개괄적으로 이해할 수 있도록 배려하 여야 할 것으로 사료된다.

\section{한류와 난류 색상}

작은 대양이라고 불리는 동해는 태평양이나 대서양 과 같은 한류와 난류계가 잘 발달되어 있다. 동해 중 앙부에서는 북쪽의 차가운 수괴와 남쪽의 따뜻한 수 괴가 $40^{\circ} \mathrm{N}$ 부근에서 만나 열전선(thermal front)을 형 성하고 있는데(Park et al., 2004; Park et al., 2007), 이를 동해의 극전선(subpolar front)라고 부른다. 일반 적으로 난류는 상대적으로 따뜻한 남쪽에서 북쪽으로 흐르면서 남쪽의 잉여 열을 북쪽 극지방으로 이동시 켜서 해양이 열적 균형을 이룰 수 있도록 조절하고 있다. 마찬가지로 한류도 극지방에서 남쪽으로 이동하 여 전체적인 열적 균형에 기여하고 있다. 특히 한류와 난류의 분포와 변동은 전 세계 기상, 기후 및 해양 생 태계에 다양한 영향을 주기 때문에 해류도에서 정확 한 한류와 난류의 정보를 제공할 필요가 있다.

외국 도서에 제시되어 있는 전 세계 대양의 해류 도는 해류 벡터뿐만 아니라 한류와 난류를 색상으로 구분하고 있다(e.g., Garrison, 2004). 교과서 삽화는 시각적으로 중요한 표상 요소이고, 평면적인 그림 외 에 색상 표현도 학습자에게 추가 정보를 제공할 수 있다(이기영, 2007; Pozzer and Roth, 2003). 따라서 일부 현행 교과서에서 난류와 한류의 기본적인 색상 구분을 하지 않고 있는 해류도는 개선이 필요하다. 최근의 다양한 영상 매체와 시각적 교육 자료에 익 숙해있는 학습자에게는 보다 다양한 색상 정보를 제 공하는 것이 학습 효과를 더욱 높일 수 있다.

이러한 해류의 색상 구분을 기준으로 Table 3의 $\mathrm{C} 11$ 을 분석한 결과, 25 종 교과서 중 23 종에 달하는 대부분의 교과서가 난류와 한류를 구분하고 있었다. 그러나 M1 교과서의 경우 한류와 난류를 구분하여 표현하지 않고 같은 색상을 사용하였고, M6 교과서 는 교과서 내용과 관련하여 문제를 출제하면서 해류 도를 사용하였는데 해류의 형태만을 단순하게 표시하 였다. 대부분의 교과서가 난류는 붉은 색 계통으로, 
한류는 푸른 색 계통으로 표현하였으나 이러한 계통 외에 다른 계열의 색상을 사용한 교과서도 많이 발 견되었다. 예를 들면 $\mathrm{M} 4$ 에서 난류를 노란색 계열, $\mathrm{Ha} 4$ 에서 한류를 보라색 계열을 사용하였다. 그런데 $\mathrm{Ha} 4$ 는 한류를 보라색으로 표시하였지만 $\mathrm{Ha} 5$ 에서 난 류를 보라색 계열로 표시하여 학습자에게 혼란을 일 으킬 수 있다. 해류도의 색상에 대해서도 교과서 내 용에서는 구체적으로 언급하고 있지 않다. 따라서 이 러한 해류의 색상 선택도 통일을 하여 학습자의 오 개념 유발을 감소시킬 수 있도록 하여야 할 것이다.

\section{해류의 크기}

해류를 한류와 난류로 색상으로 구분하여 제공하는 것도 중요하지만, 유속의 크기를 색상의 명암이나 채 도 변화를 통해서 정량적으로 표현하는 것도 시각적 으로 중요할 수 있다. 대부분의 교과서들은 해류의 크기를 해류의 폭이나 화살표의 크기를 이용하여 정 성적이지만 정량적인 정보를 제공하고 있었다. 해류 의 크기의 정도를 표현하였는지를 해류의 크기를 세 단계로 나누어 표현한 경우를 적합, 두 단계로 나눈 경우를 일부 적합, 그리고 한가지의 크기로 표현한 경우를 부적합으로 나누어 Table 3의 $\mathrm{C} 12$ 에 표기하 였다. 이 기준으로 볼 때 적합하다고 판정된 경우는 중학교 교과서가 $\mathrm{M} 3, \mathrm{M} 8$ 로 2종, 고등학교 과학 교 과서가 $\mathrm{Ha} 1, \mathrm{Ha} 2, \mathrm{Ha} 5, \mathrm{Ha} 8, \mathrm{Ha} 10, \mathrm{Ha} 11, \mathrm{Ha} 12$ 로 7종, 지구과학 $\mathrm{I}$ 교과서가 $\mathrm{Hb} 2, \mathrm{Hb} 4, \mathrm{Hb} 5$ 로 3종으로 총 12 종이 있었다.

해류의 정량적인 크기를 제시하는 것이 매우 중요 한데도 불구하고, 오랜 동안 해양학자들의 노력에도 불구하고 아쉽게도 우리나라 주변 바다를 모두 포함 하는 해류장을 정량적으로 표현할 만큼 현재 국내 해양학계에 해류 자료가 축적되어 있지 않는 것도 사실이다. 해류의 크기를 해류 경로의 폭으로 표현하 는 것은 문제가 발생할 수도 있다. 실제 해류가 넓은 해역을 지나가지만 해류 유속 자체는 낮은 경우가 있고, 또 좁은 해협을 지나가더라고 폭은 좁지만 유 속이 매우 강한 경우도 있다. 그런데 현행 교과서의 해류도와 같이 앞으로도 해류의 너비로서 유속을 표 현하게 된다면 해류도를 깊이 탐구하는 학생들에게는 잘못된 정보가 전달될 우려가 있다. 따라서 향후에는 해류의 유속과 실제 너비를 고려하여 해류 모식도를 작성하는 방안이 강구되어야 할 것으로 사료된다. 이 외에도 해류를 연속적인 흐름으로 표현한 교과서도
있고, 또 연속적이나 중간에 끊어서 그린 경우도 있 는데 $\mathrm{M} 1, \mathrm{M} 4, \mathrm{M} 9, \mathrm{Ha} 3, \mathrm{Ha} 8$ 의 총 5종 교과서가 이 부류에 포함되었다.

\section{출처 및 참고문헌}

교과서의 해류도는 연구 논문으로 학술지에 게재되 었거나 국가 기관에서 제시하였거나 혹은 해양학 관 련 출판 도서를 참고하여 작성되어야 한다. 따라서 교과서에서 제시한 해류도는 반드시 참고문헌 및 출 처를 제시하는 것이 바람직하다. 그러나 Table 3의 $\mathrm{C} 13$ 항목의 분석 결과에서 보는 바와 같이 출처를 아예 제시하지 않은 부적합한 교과서가 총 13종에 달하였는데, 이는 분석교과서의 절반이 넘는 상당한 비중을 차지하였다. 고등학교 과학 교과서의 경우엔 $\mathrm{Ha} 1$ 부터 $\mathrm{Ha} 12$ 까지 모든 교과서가 참고문헌을 제시 하지 않았고, 중학교 교과서 중엔 M5와 M7 교과서 가 참고문헌을 제시하지 않았다(Table 6). Table 6에 서는 참고문헌이 없는 교과서는 제외하였다.

참고문헌이 저서인 경우에는 저서명, 저자, 출판사, 출판연도, 페이지 등을 모두 기록하는 것이 바람직하 다고 판단된다. 따라서 이 중 세 가지 이상을 제시하 는 경우를 적합하다고 판단하였고, 홈페이지인 경우 엔 해당 홈페이지 주소와 웹사이트를 최종 열람한 날짜까지 기재한 것을 적합하다고 판단하였다. 중학 교 교과서인 $\mathrm{M} 1, \mathrm{M} 2, \mathrm{M} 3, \mathrm{M} 9$ 의 4종과 지구과학 I 교과서인 $\mathrm{Hb} 3$ 이 이에 해당하였다. 참고문헌을 제시 하였으나 이 조건을 충족시키지 못한 경우는 일부 부적합하다고 판단하였고, 중학교 교과서 중 $\mathrm{M} 6$, $\mathrm{M} 8 \mathrm{M} 3$ 종과 지구과학 I 교과서의 $\mathrm{Hb} 1$ 부터 $\mathrm{Hb} 6$ 까지 중 $\mathrm{Hb} 3$ 을 제외한 5종이 이에 해당하였다. M6, M8, $\mathrm{Hb} 2$ 교과서는 모두 웹사이트가 출처인데도 불구하고 홈페이지 주소를 제시하지 않았다. 가장 빈번하게 사 용되어온 참고문헌은 1998년에 출판된 지구과학개론 (한국지구과학회, 1998)과 한국근해해상지(이석우, 1992)로 밝혀졌다. 지구과학개론을 참고한 해류도는 교과서 $\mathrm{M} 1$ 과 $\mathrm{M} 2$ 로 2종이며 한국근해해상지를 참고 한 교과서는 $\mathrm{M} 3, \mathrm{M} 4, \mathrm{M} 9, \mathrm{Hb} 1, \mathrm{Hb} 3, \mathrm{Hb} 5, \mathrm{Hb} 6$ 로 7종이 있었고, 이 중에서 $\mathrm{Hb} 5, \mathrm{Hb} 6$ 가 제시한 참고문 헌의 발행 연도는 1999년으로 되어있었다. 그런데 한 국근해해상지는 1992년에 발행되었고, 1999년에는 동일한 책자가 내용의 변화 없이 추가로 인쇄된 경 우(1판 2쇄)에 해당하므로 참고문헌은 1999년이 아닌 1992년으로 명시해야 한다. 
Table 6. Information of references in the textbooks

\begin{tabular}{|c|c|c|c|c|c|c|}
\hline Symbol & Reference & Author & Year & Publisher & Region & Page \\
\hline M1 & 지구과학개론 & - & - & 교학연구사 & - & 260 \\
\hline M2 & 지구과학개론 & 한국지구과학회 & 1998 & 교학연구사 & 서울 & - \\
\hline M3 & 한국근해해상지 & 이석우 & 1992 & 집문당 & - & - \\
\hline M4 & 한국근해해상지 & - & - & - & - & - \\
\hline M6 & 국립해양조사원 & - & - & - & - & - \\
\hline M8 & 한국해양자료센터 & - & - & - & - & - \\
\hline M9 & 한국근해해상지 & 이석우 & 1992 & 집문당 & - & 66 \\
\hline $\mathrm{Hb} 1$ & 한국근해해상지 & - & 1992 & - & - & - \\
\hline $\mathrm{Hb} 2$ & 기상청 & - & - & - & - & - \\
\hline $\mathrm{Hb} 3$ & 한국근해해상지 & 이석우 & 1992 & 집문당 & - & - \\
\hline $\mathrm{Hb} 4$ & 지구환경과학 & - & - & - & - & - \\
\hline $\mathrm{Hb} 5$ & 한국근해해상지 & - & 1999 & - & - & - \\
\hline Hb6 & 한국근해해상지 & - & 1999 & - & - & - \\
\hline
\end{tabular}

또한 $\mathrm{M} 1$ 과 $\mathrm{M} 2$ 의 경우 동일한 참고문헌을 활용하 였다고 하였으나 시각적으로 보기에 해류도가 상이하 였으며, M3, M4, M9, $\mathrm{Hb} 1, \mathrm{Hb} 3, \mathrm{Hb} 5, \mathrm{Hb} 6$ 도 마찬 가지로 서로 많은 차이를 보였다. M1, M9, Ha4, $\mathrm{Ha} 9$ 교과서에서는 북한한류와 리만해류가 남하하다 다시 되돌아 북상하는 모습의 해류도를 제시하였는 데, 이는 지구과학개론에 제시된 해류도와 유사한 양 상을 보였다. 동일한 문헌을 참고하였음에도 불구하 고 큰 차이가 나거나 다른 참고문헌을 제시하였음에 도 거의 같은 모습의 해류도를 표현하는 것은 참고 문헌을 잘못 제시하였거나, 해류에 관한 전문적인 지 식이 없는 비전문 일러스트레이터가 해류도 작성 작 업을 함으로써 본래의 해류도와 차이가 큰 해류도를 제작하여 교과서에 삽입하였을 가능성이 클 것으로 유추된다. 그 외 여러 문제점들이 해류도들 사이에서 발견되었는데 인용한 참고문헌이 동일한데도 불구하 고 교과서마다 다른 해류도를 제시한 경우도 있었고, 또 인용하였다고 한 연구 논문에는 교과서 해류도와 해류 양상이 다르게 제시된 것도 있었다.

\section{해류 이름}

동해를 통과하는 난류는 앞에서 설명한 바와 같이 크게 대마난류의 제 1 분지인 대마난류 근해 분지와 제 3 분지인 동한난류, 그리고 두 분지 사이에 있는 동해 중앙부의 대마난류 제 2 분지가 있다. 또한 북쪽 에서 내려오는 리만해류와 북한한류가 존재한다. 러 시아 연안을 따라 남하하는 해류에 대하여 과학논문 및 교과서는 ‘리만해류'와 '리만한류'로 혼용하여 사
용하고 있었다. Uda(1934)는 Liman Current라고 명 명했고, Yurasov and Yarichin(1991)은 러시아 연안 (Primorye coast)을 따라 남하한다고 하여 Primorskiy Current 또는 Shrenk Current라고도 불렀다. 해양과학 용어사전(한국해양학회, 2005)과 지구과학사전(한국지 구과학회, 2009)에서는 리만해류로 정의하고 있다. 10종(M1, M5, M9, Ha4, Ha9, Ha10, Ha11, Hb2, $\mathrm{Hb} 5, \mathrm{Hb} 6)$ 의 교과서들은 '리만해류'로 표현하였고, 4 종의 교과서는 해류의 이름을 제시하지 않았으며, 그 외 나머지 11종 교과서는 '리만한류'로 표시하고 있 었다. 교과서에서는 해류를 크게 한류와 난류로 구분 하여 기술하고 있는 점 등을 고려하여 용어 선택에 관한 좀 더 깊이 있는 연구가 필요하며 추후 학계의 의견을 수렴하여 해류의 용어가 통일되어야 할 것으 로 판단된다.

현재 학계에서는 대마난류 제 1 분지는 대마난류로, 제 3 분지는 동한난류로 명명하고, 제 2 분지에 대해서 는 공통적으로 부르는 통일된 이름이 없고 대마난류 의 제 2 분지 혹은 영어 표현으로 'Offshore Branch $(\mathrm{OB})$ '라고 부른다. 따라서 이와 같은 기준을 근거로 두 개의 분지로 표현한 교과서의 경우는 동한난류와 대마난류, 세 개의 분지로 표현한 경우는 대마난류의 제 2 분지를 포함하여 기술하는 것이 적합하다고 판 단하여 Table 3의 $\mathrm{C} 14$ 와 같이 분석 결과를 나타내었 다. 적합하다고 판단된 경우는 중학교 과학 교과서 중 $\mathrm{M} 3, \mathrm{M} 5$ 의 2종과 고등학교 과학 교과서 중 $\mathrm{Ha} 1$, $\mathrm{Ha} 2, \mathrm{Ha} 7, \mathrm{Ha} 10$, 지구과학 I 교과서 중에는 $\mathrm{Hb} 2$, $\mathrm{Hb} 3, \mathrm{Hb} 4, \mathrm{Hb}$ 로 모두 두 개의 분지로 표현한 해류 


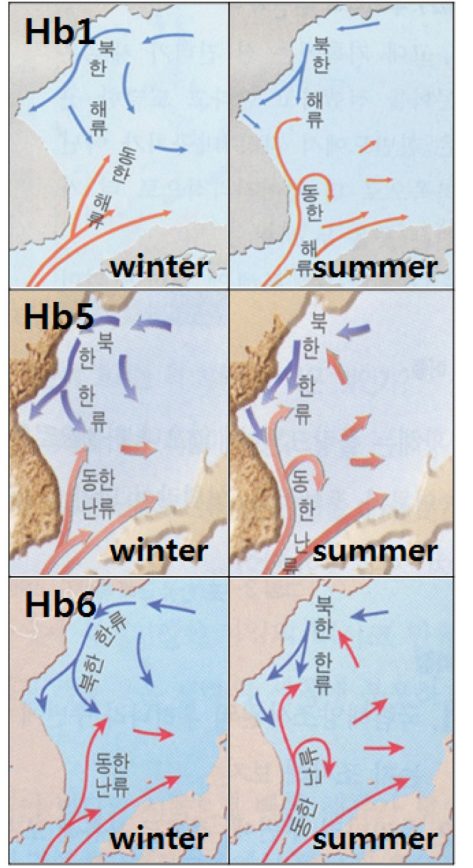

Fig. 14. Seasonal current maps in the secondary school science textbooks, where the symbol represents the notation of each textbook.

도였다. 해류의 이름을 한 개 이상 누락한 경우는 일 부 부적합하다 판단하였고, 모두 누락한 경우는 부적 합하다 판단하였다. 대마난류를 3 개의 분지로 표현한 교과서를 분석하면 제 2 분지의 이름을 표기한 교과 서는 한 종도 없었으며, 모두 제 3 분지와 제 2 분지를 동한난류로 통일하여 표기하였다. $\mathrm{Ha} 8$ 의 경우 대마 난류 표기를 누락하였고, $\mathrm{Ha} 9$ 의 경우는 동한난류의 표기를 누락하였다. M6는 교과서 속의 문제 출제를 위하여 해류도를 제시하였기 때문에 해류도 이름을 제시하지 않아서 부적합하다 판단하였다.

\section{계절별 해류도}

Fig. 14는 $\mathrm{Hb} 1, \mathrm{Hb} 5, \mathrm{Hb} 6$ 교과서에서 제시하고 있 는 계절별 해류도를 나타낸 것이다. 이 계절별 해류 도들은 $\mathrm{Hb} 1, \mathrm{Hb} 5, \mathrm{Hb} 6$ 교과서가 동일한 참고문헌인 한국근해해상지(이석우, 1992)를 참고하였기 때문에 유사한 양상을 보였다. 평균 해류도와는 다르게 계절 에 따른 특성을 겨울과 여름 두 가지로 나누어 제시 하였는데 대체로 겨울에 동한난류가 연안에서 이안하 여 북상하는 모습이고 여름에는 연안 가까이에서 더 높은 위도까지 북상하는 모습으로 나타내었다. 또한
여름에 동한난류가 이안한 후 약하지만 남쪽방향으로 시계방향의 와류를 표현한 것을 볼 수 있다. 이는 울 릉분지의 난수성 소용돌이를 나타내려는 의도가 있었 을 것으로 유추된다. 한류는 여름에 비해 겨울에 더 길고 뚜렷한 양상을 보이도록 제시하였으나 실제로 리만해류의 경우 여름철에 가장 강하게 나타나고, 북 한한류도 표층 아래에서는 여름철에 대한해협까지 내 려온다는 보고가 있어(김영호와 민홍식, 2008) 몇몇 연구와 차이를 보였다. 앞서 언급한 바와 같이 동해 는 작지만 다양한 해양현상들이 존재하고 있고, 또 한류와 난류의 변동성도 커서 하나의 평균 해류도를 작성하는 것도 쉬운 일이 아닌데 계절별 해류도까지 교과서에 제시하기에는 해양 관측 자료가 절대적으로 부족한 것이 사실이다.

이러한 관측의 한계점을 고려하여 Table 3 의 $\mathrm{C} 15$ 는 적합과 부적합의 문제를 떠나 계절별 해류도를 제시한 경우를 진한 회색으로 표시하였다. 이에 해당 하는 경우는 $\mathrm{Hb} 5, \mathrm{Hb} 6$ 이며, 계절별 해류도만을 제시 하여 Table 3에는 제시되지 않은 $\mathrm{Hbl}$ 까지 총 3 종의 지구과학 I 교과서에서 계절별 해류도를 제시하였다. $\mathrm{Hb} 5$ 와 $\mathrm{Hb} 6$ 은 평균 해류도와 계절별 해류도를 모두 제시하였다.

\section{결론 및 제언}

교과서의 삽화는 해당 교육 내용에 대한 학생들의 동기를 유발하며 학습을 안내하는 역할을 동시에 수 행하고 있다. 특히 과학 교과서에서 내용상이나 표현 상의 오류를 포함한 삽화를 제시할 경우에 학생들의 개념 형성에 있어서 심각한 저해요인이 될 수 있기 때문에 일반교과서보다 과학 교과서에 사용되는 삽화 는 더 중요하다. 과학 및 지구과학 교과서는 우리나 라 주변해의 해류도에 대하여 지금까지 학계의 과학 적인 연구 결과와 가장 근접하는 종합적인 해류모식 도를 제시하고 있어야 한다. 그럼에도 불구하고 앞서 언급한 바와 같이 27 종 교과서에서 상당히 많은 오 류를 가진 해류도를 제시하고 있다. 따라서 이러한 과학 및 지구과학 교과서의 해류도에서 나타나는 오 류 문제를 해결하기 위해서는 학계와 교과서 집필진 의 적극적인 개선의 노력이 필요하다.

그러나 아쉽게도 국내 해양학계에서도 아직까지 통 일된 해류모식도가 없는 것이 사실이다. 대부분의 해 류도가 일제시대 $\mathrm{Uda}(1934)$ 의 문헌을 참고하여 작성 
되었고, 또 여러 과학 논문들도 해류도를 제시하고 있지만 연구 목적에 맞는 단편적인 해류도를 제시하 고 있어서 동해 전체의 해류를 대표할 수 있는 통일 된 해류모식도가 없는 실정이다. 앞으로 학계의 끊임 없는 관측과 부단한 노력으로 우리나라의 주변해의 해류를 대표할 수 있는 해류모식도를 제작하여야 한다. 따라서 해류도를 제작할 때 여러 가지 문제점 들을 미리 정확히 파악하고 있어야 하며, 표준화된 방법으로 제작할 필요성이 있다. 앞서 언급한 바와 같이 과학적 연구 논문에 나오는 해류도는 연구자의 연구 주제와 관심이 반영되어서 제작된 것이기 때문 에 대표성이 부족하다. 예를 들면, 중규모 소용돌이 에 관심이 있는 연구자는 해류도에 소용돌이가 빈번 하게 나타나는 위치와 형태에 집중하고 있어서 전체 해류도로 활용하기에 적합하지 않는 경우가 많다.

또한 학계에 보고되는 해류에 대한 정보는 다양한 관측 장비와 방법에 의존하여서 관측 방법에 따른 차이점 등 여러 가지 문제점이 내재되어 있다. 예를 들면 해류에 대한 정보에는 관측기기에 따른 상이성 이 있고, 인공위성을 활용할 경우 인공위성의 긴 관 측주기에 따른 문제점, 상대해류장을 관측하여 절대 해류장을 알 수 없는 한계점, 또한 극초단파 원격탐 사 측기의 특성상 연안 $50 \mathrm{~km}$ 이내에는 관측이 불가 능한 점 등 다양한 문제점들이 있다. 표층 부이, $\mathrm{HF}$ 레이더, 위성 고도계, 초음파해류계를 이용한 해류 관측, 유속계를 활용한 해류 및 해저케이블의 전압차 를 활용한 해류 관측들은 모두 다양한 방법과 원리 에 의존하여 직접적 혹은 간접적으로 해류에 관한 정보를 얻기 때문에 문제점이 발생할 수밖에 없다. 교과서에 등장하는 해류도는 학생들에게 해류 전반에 대한 지식을 전달해야 하기 때문에 해류 전반의 특 징이 잘 드러나도록 전체적으로 통일된 해류도여야 한다.

현재 해류도 작성을 할 때 대부분 정성적으로 접 근하고 있으나 정량적인 정보도 줄 수 있고 또 시각 적 대비 효과도 크도록 표현하는 것이 바람직하다. 현행교과서는 일반적으로 유속 벡터의 크기를 너비로 표현하고 있는데, 실제로 넓은 해역을 약하게 지나가 는 해류도 있고 대한해협의 서수도와 같이 좁은 해 역을 빠르게 지나가는 경우도 있어서 어떤 형식으로 든 제대로 된 정보를 해류도에 표현하여야 할 것이 다. 동일 색상이지만 명암이나 채도 변화를 통하여 유속의 크기 정보를 주고, 해류의 너비는 실제 해류
가 존재하는 구간에 대해 표시하는 것이 오히려 더 적절하다고 판단된다. 해양학계에서도 동해 모든 해 역에서의 평균된 유속의 크기를 알 수 없기 때문에 유속의 절대값 범위를 현재 학계에서 알고 있는 과 학적 지식을 기반으로 몇 개의 구간으로 나누어 정 량적 정보를 제시하여야 한다.

교과서의 해류도 색상이 붉은 계통과 푸른 계통의 다양한 색상을 사용하고 있다. 보라색, 주황색 등으 로 해류를 표현한 경우도 있고, 유속의 크기와 상관 없이 명암을 표현한 경우도 많다. 따라서 유속의 크 기를 고려한 통일된 계열의 색상도 정의할 필요가 있다. 평균된 유속장에 대한 정보가 없는 공간도 많 기 때문에 동해에 대해서 해류도의 계절적 변화를 제시하는 것은 현재 학계의 수준으로는 가능하지 않 다. 몇몇 교과서에 해류의 계절변화도를 나타내고 있 으나 동해의 경우는 하나의 평균된 해류도가 더 적 합할 것으로 사료되며, 황해의 경우는 계절변화가 뚜 렷하기 때문에 여름과 겨울의 두 장 정도의 해류도 는 제시하여야 할 것으로 판단된다. 또한 지금까지의 해류도는 우리나라의 해안선만을 그리고 동해 내부에 해류를 표시하였으나 해류는 해저 지형의 영향을 많 이 받고 있고 또 학생들의 이해를 높이기 위해서도 해저 지형을 먼저 그리고 그 위에 해류를 표시하는 방법이 더 적절할 것이다. 복잡성을 피하기 위하여 편의상 수심 $2000 \mathrm{~m}$ 등수심선 하나만을 제시하는 것 이 좋은 방법으로 판단된다.

교과서 내용의 개정 속도를 과학 기술의 발전 속 도와 비교해 볼 때 해류도 측면에서는 양자가 모두 느리게 진행되는 것이 사실이다. 과학계의 새로운 발 견이 즉각적으로 교육계에 반영되는 것 또한 바람직 하지 않은 측면도 있다. 새로운 발견이더라도 시간이 지나 다른 연구에 의해 뒤바뀔 수도 있기 때문에 과 학계에서 오랜 논의와 검증을 통해 통일된 의견으로 수렴되고 확립이 되어야만 교과서라는 형식을 통해 학생들에게 전달될 수 있는 것이다. 그러나 해류도 측면에서 볼 때, 본 연구에서 분석한 교과서 내용은 과거 확립된 과학적 지식에 비추어 볼 때 지나친 오 류를 포함하고 있는 것이 사실이다. 교육계에서는 교 과서에 필요한 내용을 과학계에 요구할 수 있고, 과 학계는 통일된 의견을 교과서에서 채택하여 사용할 수 있도록 추천할 수도 있다. 따라서 과학계와 교육 계는 서로 유기적인 관계를 맺어서 통론으로 인지되 는 과학적 지식과 정보는 교육 현장에 직접적으로 
활용할 수 있도록 지원하여야 할 것이다. 따라서 교 과서 해류도의 오류를 분석한 본 연구는 우리나라 주변해의 표준해류도를 작성하기 위한 첫 걸음이 될 것으로 예상되며, 추후 국내 연구진 및 여러 국가기 관이 서로 협력하여 통일된 해류모식도를 제작하기 위한 논의가 활발히 이루어질 것으로 기대된다.

해류 및 해양교육의 교육적 목표를 달성하기 위해 서는 교과서 개발과정에서 과학적으로 정확한 해류도 를 제시하려는 노력이 필요하다. 그런데 본 연구에서 사용된 과학 교과서의 집필진을 분석해 본 결과 전 체 259명(중복포함) 중에서 해양관련 전공자는 단지 4명(중복포함 시 7명)으로 나타났다. 그 동안 해양, 대기, 천문, 지질 등 지구과학 각 분야의 전문가들이 교과서 집필 과정에 집필진으로 골고루 참여하는 것 이 현실적으로 어려웠다. 또한 과학적 지식이 없는 일러스트레이터가 편집진에 참여하여 동일한 참고문 헌을 참고하였음에도 불구하고 해류를 서로 다르게 나타내는 오류를 범한 것으로 유추된다. 교과서 삽화 를 비롯한 집필과정은 가능한 해당 분야의 전문가가 맡고 전문가의 철저한 검정을 반드시 거치도록 하여 교과서에서 발견되는 과학적 오류들을 줄여야 할 것 이다. 앞으로 교육과정해설서는 제작되지 않을 방침 이어서 이러한 삽화 제작에 대한 지침이나 유의사항 이 교과서 집필진에게 전달되기 더욱 어려운 상황이 될 수 있다. 따라서 여러 가지 가능한 방법을 동원하 여 교과서 삽화의 오류를 줄여나가는 노력이 더욱 절실히 요구된다.

최근 급격한 기후변화에 대해서 해양의 역할이 점 점 더 강조되고 있고 있다. 이러한 추세와 더불어 기 후 변화와 밀접하게 관련되어 있는 해양의 순환과 해류를 이해할 수 있고, 해양 전반에 대한 해양학적 소양을 두루 갖춘 인재 육성이 중요하다. 해류도는 지구과학 및 해양 교육에 있어 핵심적인 요소 중의 하나이기 때문에 학생들이 오개념을 가지지 않도록 교과서를 통하여 정확한 정보를 제공해 주어야 한다. 과학적으로 오류가 없는 해류도를 통해 해양 교육이 이루진다면 동해뿐만 아니라 우리나라 주변 해양의 변화를 제대로 파악할 수 있으며 나아가서는 지구 환경 변화 및 기후변화에 대한 해양의 중대한 역할 을 이해할 수 있게 된다. 또한 우리의 일상생활과 바 다와의 관련성에 대하여 학생들의 이해가 촉진되어 탐구 능력이 신장될 것이고, 더 나아가 과학 - 사회 · 환경의 상호 관계를 올바르게 인식하여 해양과 관련
된 다양한 사회적 쟁점에 대하여 과학적 사고력, 창 의적 사고력 및 의사소통 능력을 함양할 수 있을 것 이다.

\section{사 사}

이 연구는 해양 자료의 교육적 활용을 위하여 국립 해양조사원 해류도제작 사업과 국토해양부의 EAST-1 사업에 의해 일부 지원되었습니다. 논문을 세밀히 심 사해주신 두 심사위원님께 감사드립니다. 귀중한 의견 을 주신 양우헌 교수님께도 감사드립니다.

\section{참고문헌}

강만식, 정창희, 이원식, 한인섭, 권숙일, 이민호, 박수인, 윤용, 이강석, 이태욱, 정규호, 양영주, 2001, 고등학교 과학. 교학사, 서울, $388 \mathrm{p}$.

강만식, 정창희, 이원식, 한인섭, 박은호, 이창진, 김일회, 장병기, 정병훈, 윤용, 이태욱, 한천옥, 2000 , 중학교 과 학1. 교학사, 서울, $294 \mathrm{p}$.

경재복, 윤일회, 이경훈, 김기룡, 황원기, 이기영, 2002 , 지 구과학 I. 중앙교육진흥연구소, 서울, 268 p.

국동식, 2003 , 온실효과 개념에 대한 오개념 원인으로서의 10 학년 과학 교과서 분석. 한국과학교육학회지, 23 , 592-598.

국립해양조사원: http://www.khoa.go.kr/info/seawater_eastsea. asp (2010. 7. 5.)

김영호, 민홍식, 2008 , 동해 재분석 자료에 나타난 북한한 류의 계절 및 경년변동성. Ocean and Polar Research, 30, 21-31.

김정률, 고현덕, 김재현, 김남일, 임용우, 동효관, 김선주, 남철주, 김영순, 이준용, 2000 , 중학교 과학1. 블랙박스, 서울, $288 \mathrm{p}$.

김찬종, 김희백, 박시진, 오차환, 양재철, 장흥식, 정진문, 조현수, 최후남, 한송희, 현종오, 홍경희, 2000 , 중학교 과학1. 디딤돌, 서울, 295 p.

김찬종, 서만석, 김희백, 심재호, 현종오, 한인옥, 권성기, 박성식, 2001, 고등학교 과학. 디딤돌, 서울, 360 p.

김희수, 정남식, 신동원, 박정웅, 이정식, 한홍열, 박용선, 2002, 지구과학 I. 천재교육, 서울, 248 p.

박경애, 최지영, 2009 , 중등 과학교과서에서 사용된 염분 단위 분석 및 단위 개정을 위한 제안. 한국지구과학회 지, 30, 513-526.

박봉상, 김윤우, 홍달식, 박문수, 정대영, 심국석, 심중섭, 최진복, 장정찬, 최병수, 진만식, 2000 , 중학교 과학1. 동화사, 서울, $280 \mathrm{p}$.

성민웅, 김봉곤, 조성동, 강대훈, 강충호, 구자옥, 노일환, 이용철, 임태훈, 최범선, 한은택, 2001 , 고등학교 과학. 문원각, 서울, $416 \mathrm{p}$.

소현수, 안태인, 최승언, 박건식, 이영만, 목창수, 김종권, 
김득호, 구수길, 박완규, 김완섭, 김영산, 2000 , 중학교 과학1. 두산동아, 서울, $271 \mathrm{p}$.

송호봉, 정용순, 유병선, 이윤상, 김여상, 정태연, 이하원, 윤덕열, 2001, 고등학교 과학. 홍진 P\&M, 서울, $397 \mathrm{p}$.

오원근, 2003 , 학생의 개념과 구성주의적 과학교육. 과학교 육논총, $19,1-18$.

우규환, 이춘우, 오두환, 김영유, 경재복, 이경훈, 박태윤, 이영직, 백수관, 김병인, 김봉래, 이기영, 2001, 고등학 교 과학. 중앙교육진흥연구소, 서울, 400 p.

우종옥, 정진우, 위수민, 임청환, 홍성일, 이석형, 2002, 지 구과학 I. 교학사, 서울, $222 \mathrm{p}$.

이광만, 허동, 이경운, 정문호, 방태철, 이기성, 안태금, 정 상윤, 복완근, 정익현, 박병훈, 박정일, 정수도, 김경수, 박자극, 송양호, 이천기, 2000 , 중학교 과학. 지학사, 서 울, $279 \mathrm{p}$.

이규석, 이창진, 김정률, 이용준, 강진철, 김재현, 2002 , 지 구과학 I. 대한교과서, 서울, $248 \mathrm{p}$.

이규석, 조희영, 박봉상, 박문수, 심국석, 심중섭, 최진복, 장정찬, 이창진, 이용준, 2001 , 고등학교 과학. 대한교과 서, 서울, $391 \mathrm{p}$.

이기영, 2007, 6차와 7차 교육과정에 따른 고등학교 지구 과학 교과서에 사용된 사진과 삽화의 기능 및 구조 비 교 분석. 한국지구과학회지, 28, 811-824.

이면우, 장병기, 고재덕, 윤상학, 이진승, 여상인, 김홍석, 임채성, 배진호, 백승용, 이성진, 최변각, 2003, 고등학 교 과학. 지학사, 서울, $360 \mathrm{p}$.

이문원, 전성용, 권석민, 진만식, 신석주, 임부철, 2002, 지 구과학 I. 금성출판사, 서울, $284 \mathrm{p}$.

이문원, 전성용, 최병수, 권석민, 노태희, 허성일, 김출배, 강석진, 박희송, 김경호, 김규상, 채광표, 김진만, 정대영, 2002 , 고등학교 과학. 금성출판사, 서울, 416 p.

이석우, 1992, 한국근해해상지. 집문당, 서울, $334 \mathrm{p}$.

이성묵, 채광표, 김기대, 노태희, 정지오, 서인호, 김영수, 김윤택, 이세영, 이문원, 권석민, 손영운, 2000 , 중학교 과학1. 금성출판사, 서울, $249 \mathrm{p}$.

이연우, 강석본, 김인석, 김성진, 이진우, 안종제, 배미정, 전화영, 2001 , 고등학교 과학. 이젠미디어, 서울, 384 p.

정완호, 권재술, 김대수, 김범기, 신영준, 우종옥, 이길재, 정진우, 최병순, 황원기, 2001 , 고등학교 과학(정). 교학 사, 서울, $352 \mathrm{p}$.

정완호, 우종옥, 권재술, 김범기, 최병순, 정진우, 김성하, 백성혜, 이석형, 이봉호, 2000 , 중학교 과학(정)1. 교학 사, 서울, $299 \mathrm{p}$.

차동우, 김희수, 이명석, 이현주, 최종한, 이복영, 옥준석, 윤세진, 이원경, 정남식, 신동원, 2001 , 고등학교 과학. 천재교육, 서울, $356 \mathrm{p}$.

채동현, 2010 , 지구과학 I 교과서의 단열변화 정의, 삽화, 실험에 대한 예비 교사들의 반응. 한국지구과학회지, 31, 762-771.

최경희, 김숙진, 1996 , 과학 교과서 선정과 평가에 관련된 교사들의 인식조사와 과학 교과서 평가틀 개발에 관한 연구. 한국과학교육학회지, $16,303-313$.

최돈형, 김동영, 김봉래, 김재영, 노석구, 신영준, 이기영,
이대형, 이면우, 이명제, 이상인, 전영석, 2000, 중학교 과학1. 대일도서, 서울, $289 \mathrm{p}$.

최승일, 조희형, 1987, 고등학교 생물1의 세포분열, 생식, 수정개념에 대한 오인 분석. 한국과학교육학회지, 7 , 19-31.

한국지구과학회, 1998 , 지구과학개론. 교학연구사, 서울, $818 \mathrm{p}$.

한국지구과학회, 2009, 지구과학사전. 북스힐, 서울, $1237 \mathrm{p}$. 한국해양학회, 2005, 해양과학용어사전. 아카데미서적, 서 울, $749 \mathrm{p}$.

허창회, 박병훈, 정성표, 김병국, 2002 , 지구과학 I. 지학사, 서울, $256 \mathrm{p}$.

현종오, 이진승, 이응신, 이경호, 조광희, 한인옥, 정대홍, 최원호, 이태원, 김희백, 이상인, 김찬종, 박정웅, 서만석, 이태형, 이인선, 2007, 고등학교 과학. 한국과학문화재단, 서울, $209 \mathrm{p}$.

Abraham, M.R., Grzybowski, E.B., Renner, J.W., and Marek, E.A., 1992, Understanding and misunderstanding of eights graders of five chemistry concepts found in textbook. Journal of Research in Science Teaching, 29, 105-120.

Ball, D.L. and Feiman-Nemser, S., 1988, Using textbooks and teachers' guides: A dilemma for beginning teachers and teacher educators. Curriculum Inquiry, 18, 401-422.

Beardsley, R.C., Limeburner, R., Yu, H., and Cannon, G.A., 1985, Discharge of the Changjiang (Yangtze River) into the East China Sea. Continental Shelf Research, 4, 5776.

Bryden, H.L., Longworth, H.R., and Cunningham, S.A., 2005, Slowing of the Atlantic meridional overturning circulation at $25^{\circ} \mathrm{N}$. Nature, 438, 655-657.

Chang, K.-I., Suk, M.-S., Pang, I.-C., and Teague, W.J., 2000, Observations of the Cheju Current. Journal of the Korean Society of Oceanography, 35, 129-152.

Chang, K.-I., Teague, W.J., Lyu, S., Perkins, H., Lee, D., Watts, D., Kim, Y., Mitchell, D., Lee, C., and Kim, K., 2004, Circulation and currents in the southwestern East/ Japan Sea: Overview and review. Progress In Oceanography, 61, 105-156.

Chian-Soong, B. and Yager, R.E., 1993, The inclusion of STS material in the most frequently used secondary science textbooks in the U.S. Journal of Research in Science Teaching, 30, 339-349.

Cho, K.-D., Bang, T.-J., Shim, T.-B., and Yu, H.-S., 1990, Three dimensional structure of the Ulleumg Warm Lens. Bulletin of the Korean Fisheries Society, 23, 323333.

Cho, Y.-K. and Kim, K., 1994, Two modes of salinityminimum layer water in the Ulleung Basin. La Mer, 32, 271-278.

Driver, R., Guesne, E., and Tiberghien, A., 1985, Children's ideas in science. Open University Press, Philadelphia, USA, $208 \mathrm{p}$. 
Fang, G., Zhu, B., and Zhu, Y., 1991, Water volume transport through the Taiwan Strait and the continental shelf of the East China Sea measured with current meters. In Takakno, K. (ed.), Oceanography of Asian Marginal Seas. Elsevier, Amsterdam, Netherlands, 345358.

Ganachaud, A. and Wunsch, C., 2000, Improved estimates of global ocean circulation, heat transport and mixing from hydrographic data. Nature, 408, 453-457.

Garrison, T.S., 2004, Oceanography: An invitation to marine science. Thomson Learning, California, USA, $544 \mathrm{p}$.

Gordon, A.L., Giulivi, C.F., Lee, C.M., Furey, H.H., Bower, A., and Talley, L., 2002, Japan/East Sea Intrathermocline Eddies. Journal of Physical Oceanography, 32, 1960-1974.

Hase, H., Yoon, J.-H., and Koterayama, W., 1999, The current structure of the Tsushima Warm Current along the Japanese Coast. Journal of Oceanography, 55, 217235.

Ichiye, T., 1984, Ocean hydrodynamics of the Japan and East China Seas. Elsevier Oceanography Series, Amsterdam, Netherlands, 39, 423 p.

Intergovernmental Panel on Climate Change (IPCC), 2006, Climate change 1995: The science of climate change. IPCC, 573 p.

Isoda, Y. and Yamaoka, H., 1991, Flow structure of the Tsushima Warm Current passing through the Tsushima Straits. Bulletin of the Coastal Oceanography, 28, 183194.

Johnson, G.C., McPhaden, M.J., Rowe, G.D., and McTaggart, K.E., 2000, Upper equatorial Pacific Ocean current and salinity variability during the 1996-1998 El Nino-La Nina cycle. Journal of Geophysical Research, 105, 1037-1053.

Kang, S.K., Lee, S.R., and Yum, K.-D., 1991, Tidal computation of the East China Sea. the Yellow Sea and the East Sea. Elsevier Oceanography Series, Amsterdam, Netherlands, 54, 25-48.

Katoh, O., 1994, Structure of Tsushima Current in the Southwestern Japan Sea. Journal of Oceanography, 50, 317-338.

Kawabe, M., 1982, Branching of the Tsushima Current in the Japan Sea, Part I. Data Analysis. Journal of the Oceanographical Society of Japan, 38, 95-109.

Kim, C.-H. and Kim, K., 1983, Characteristics and origin of the cold water mass along the east coast of Koea. Journal of Oceanological Society of Korea, 18, 73-83.

Kim, C.-H., Kim, K.-R., Chung, J.Y., and Yoon, H.S., 1991b, Characteristics of physical properties in the Ulleung Basin. Journal of the Oceanological Society of Korea, 26, 83-100.

Kim, K., Kim, K.-R., Min, D.H., Volkov, Y., Yoon, J.-H., and Takematsu, M., 2001, Warming and structural changes in East (Japan) Sea: A clue to future changes in global oceans. Geophysical Research Letters, 28, 3293-3296.

Kim, K. and Legeckis, R., 1986, Branching of the Tsushima Current in 1981-1983. Progress in Oceanography, 17, 265-276.

Kim, Y.-H., Kim, Y.-B., Kim, K., Chang, K.-I., Lyu, S.J., Cho, Y.-K., and Teague, W.J., 2006, Seasonal variation of the Korea Strait Bottom Cold Water and its relation to the bottom current. Geophysical Research Letters, 33, L24604.

Kubota, M., 1990, Variability of the polar front in the Japan Sea. Sora to Umi, 12, 35-44. (In Japanese)

Lavaniegos, B.E. and Ohman, M.D., 2003, Long-term changes in pelagic tunicates of the California Current. Deep Sea Research Part II: Topical Studies in Oceanography, 50, 2473-2498.

Lavaniegos, B.E. and Ohman, M.D., 2007, Coherence of long-term variations of zooplankton in two sectors of the California Current System. Progress In Oceanography, 75, 42-69.

Lee, D.-K., Lee, J.C., Lee, S.-R., and Lie, H.-J., 1997, A circulation study of the East Sea using satellite-tracked drifters 1: Tsushima Current. Journal of the Korean Fisheries Society, 30, 1021-1032.

Lee, D.K. and Niiler, P., 2005, The energetic surface circulation patterns of the Japan/East Sea. Deep Sea Research Part II: Topical Studies in Oceanography, 52, 1547-1563.

Lee, D.-K. and Niiler, P., 2010, Surface circulation in the southwestern Japan/East Sea as observed from drifters and sea surface height. Deep Sea Research Part I: Oceanographic Research Papers, 57, 1222-1232.

Lee, S.W., 1966, Seasonal and secular variations of the water volume transport across the Korea Strait. Journal of Oceanography Society, 1, 1-6.

Lie, H.-J., 1984, Coastal current and its variation along the east coast of Korea. In Ichiye, T. (ed.), Ocean hydrodynamics of the Japan and East China Seas. Elsevier Oceanography Series, Amsterdam, Netherlands, 39, 399-408.

Lie, H.-J., Cho, C.-H., Lee, J.-H., Lee, S., and Tang, Y., 2000, Seasonal variation of the Cheju Warm Current in the norther East China Sea. Journal of Oceanography, 56, 197-211.

Lynn, R.J., Baumgartner, T., Garcia, J., Collins, C.A., Hayward, T.L., Hyrenbach, K.D., Mantyla, A.W., Murphree, T., Shankle, A., Schwing, F.B., Sakuma, K.M., and Tegner, M.J., 1998, The state of the California Current, 1997-1998: transition to El Niño condition. California Cooperative Oceanic Fisheries Investigations Reports, 39, 25-49. 
Macdonald, A.M. and Wunsch, C., 1996, An estimate of global ocean circulation and heat fluxes. Nature, 382, 436-439.

Martin, S. and Kawase, M., 1998, The southern flux of sea ice in the Tatarskiy Strait, Japan Sea and the generation of the Liman Current. Journal of Marine Research, 56, 141-155.

McGowan, J.A., Cayan, D.R., and Dorman, L.M., 1998, Climate-Ocean variability and ecosystem response in the Northeast Pacific. Science, 281, 210-217.

Mooers, C.N.K., Kang, H.S., Bang, I.K., and Snowden, D.P., 2006, Some lessons learned from comparisons of numerical simulations and observations of the JES circulation. Journal of the Oceanography Society, 19, 87-95.

Moriyasu, S., 1972, The Tsushima Current. In Stommel, H. and Yoshida, K. (eds.), Kuroshio: Its physical aspects. University of Tokyo Press, Tokyo, Japan, 353-369.

Nitani, H., 1972, Beginning of the Kuroshio. In Stommel, H. and Yoshida, K. (eds.), Kuroshio: Physical aspects of the Japan Current. University of Washington Press, Seattle, USA, 129-163.

Onishi, M. and Ohtani, K., 1997, Volume transport of the Tsushima Warm Current, west of Tsugaru Strait bifurcation area. Journal of Oceanography, 53, 27-34.

Pang, I.C. and Oh, I.S., 1994, Long-period sea level variations around Korea, Japan, and Russia. Bulletin of the Korean Fisheries Society, 27, 733-753.

Park, K.A., Chung, J.Y., and Kim, K., 2004, Sea surface temperature fronts in the East (Japan) Sea and temporal variations. Geophysical Research Letters, 31, L07304, doi:10.1029/2004GL019424.

Park, K.A., Kim, K., Cornillon, P.C., and Chung, J.Y., 2006, Relationship between satellite-observed cold water along the Primorye coast and sea ice in the East (Japan) Sea. Geophysical Research Letters, 33, L10602, doi:10.1029/2005GL025611.

Park, K.A., Ullman, D.S., Kim, K., Chung, J.Y., and Kim, K.R., 2007, Spatial and temporal variability of satelliteobserved subpolar front in the East/Japan Sea. Deep Sea Research Part I: Oceanographic Research Papers, 54, 453-470, doi:10.1016/j.dsr.2006.12.010.

Park, Y.H., 1986, Water characteristics and movements of the Yellow Sea Warm Current in summer. Progress of Oceanography, 17, 243-254.

Pozzer, L.L. and Roth, W.-M., 2003, Toward a pedagogy of photographs in high school biology textbooks. Journal of Research in Science Teaching, 40, 1089-114.

Riser, S.C., Warner, M.J., and Yurasov, G.I., 1999, Circulation and mixing of water masses of Tatar Strait and the northern boundary region of the Japan Sea. Journal of Oceanography, 55, 133-156.

Senjyu, T., 1999, The Japan Sea Intermediate Water; Its characteristics and circulation. Journal of Oceanography, 55, 111-122.

Senjyu, T., Shin, H.R., Yoon, J.-H., Nagano, Z., An, H.-S., Byun, S.-K., and Lee, C.-K., 2005, Deep flow field in the Japan/East Sea as deduced from direct current measurements. Deep-Sea Research Part II: Topical Studies in Oceanography, 52, 1726-1741.

Senjyu, T. and Sudo, H., 1993, Water characteristics and circulation of the upper portion of the Japan sea proper water. Journal of Marine System, 4, 349-362.

Seung, Y.-H. and Yoon, J.-H., 1995, Some features of winter convection in the Japan Sea. Journal of Oceanography, 51, 61-73.

Shin, C.-W., Byun, S.-K., Kim, C.-S., and Seung, Y.-H., 1998, Southward intrusion of the East Sea Intermediate Water into the Ulleng Basin: Observations in 1992 and 1993. Journal of the Korean Society of Oceanography, 33, 146-156.

Suda, K. and Hidaka, K., 1932, The results of the oceanographical observations on board R.M.S 'Syunp? Maru' in the southern part of the Japan Sea in the summer of 1929, Part 1. Journal of Oceanography Imperial Marine Observation, 3, 291-375.

Sugimoto, T., 1990, A review of recent physical investigations on the straits around the Japanese Islands. In Pratt, L.J., The Physical Oceanography of Sea Straits. Kluwer Academic, Amsterdam, Netherlands, 191-209.

Tanioka, K., 1968, On the East Korean Warm Current (Tosen Warm Current). Oceanography Magazine, 20, 31-38.

Teague, W.J. and Jacobs, G.A., 2000, Current observations on the development of the Yellow Sea Warm Current. Journal of Geophysical Research, 105, 3401-3411.

Teague, W.J., Jacobs, G.A., Ko, T.Y., Chang, K.-I., and Suk, M.-S., 2003, Connectivity of the Taiwan, Cheju, and Korea Strait. Continental Shelf Research, 23, 63-77.

Teague, W.J., Tracey, K.L., Watts, D.R., Book, J.W., Chang, K.-I., Horgan, P.J., Mitchell, D.A., Suk, M.-S., Wimbush, M., and Yoon, J.-H., 2005, Observed deep circulation in the Ulleung Basin. Deep Sea Research Part II: Topical Studies in Oceanography, 52, 18021826, doi:10.1016/j.dsr2.2003.10.014.

Toba, Y., Kawamura, H., Yamashita, F., and Hanawa, K., 1984, Structure of horizontal turbulence in the Japan Sea. In Ichiye, T. (ed.), Ocean Hydrodynamics of the Japan and East China Seas. Elsevier Oceanography Series, Amsterdam, Netherlands, 39, 317-332.

Tobin, K., 1990, Research on science laboratory activities: In pursuit of better questions and answers to improve learning. School Science and Mathematics, 90, 403-418.

Uda, M., 1934, The results of simultaneous oceanographical investigations in the Japan Sea and its adjacent waters 
in May and June, 1932. Japan Imperial Fishery Experimental Stations, 5, 57-190.

Yarichin, V.G., 1980, Steady state of the Japan Sea circulation. In Pokudov, V. (ed.), Problems of Oceanography. Hydrometeoizdat, Leningrad, Russia, 4661.
Yi, S.-U., 1966, Seasonal and secular variations of the water volume transport across the Korea Strait. Journal of the Oceanological Society of Korea, 1, 7-13.

Yurasov, G.I. and Yarichin, V.G., 1991, Currents of the Japan Sea. Nauka Press, Moscow, Russia, 175 p.

2011년 8월 31일 접수

2011년 12월 5일 수정원고 접수

2011년 12월 16일 채택 